\title{
Extraction of the Rare Element Vanadium from Vanadium-Containing Materials by Chlorination Method: A Critical Review
}

\author{
Shiyuan Liu, Weihua Xue and Lijun Wang *
}

check for updates

Citation: Liu, S.; Xue, W.; Wang, L. Extraction of the Rare Element Vanadium from VanadiumContaining Materials by Chlorination Method: A Critical Review. Metals 2021, 11, 1301. https://doi.org/ $10.3390 /$ met11081301

Academic Editor: Petros E. Tsakiridis

Received: 21 July 2021

Accepted: 13 August 2021

Published: 17 August 2021

Publisher's Note: MDPI stays neutral with regard to jurisdictional claims in published maps and institutional affiliations.

Copyright: (c) 2021 by the authors. Licensee MDPI, Basel, Switzerland. This article is an open access article distributed under the terms and conditions of the Creative Commons Attribution (CC BY) license (https:/ / creativecommons.org/licenses/by/ $4.0 /)$.
Collaborative Innovation Center of Steel Technology, University of Science and Technology Beijing, Beijing 100083, China; shiyuanliu126@126.com (S.L.); 18435180612@163.com (W.X.)

* Correspondence: lijunwang@ustb.edu.cn

\begin{abstract}
Vanadium as a rare element has a wide range of applications in iron and steel production, vanadium flow batteries, catalysts, etc. In 2018, the world's total vanadium output calculated in the form of metal vanadium was $91,844 \mathrm{t}$. The raw materials for the production of vanadium products mainly include vanadium-titanium magnetite, vanadium slag, stone coal, petroleum coke, fly ash, and spent catalysts, etc. Chlorinated metallurgy has a wide range of applications in the treatment of ore, slag, solid wastes, etc. Chlorinating agent plays an important role in chlorination metallurgy, which is divided into solid $\left(\mathrm{NaCl}, \mathrm{KCl}, \mathrm{CaCl}_{2}, \mathrm{AlCl}_{3}, \mathrm{FeCl}_{2}, \mathrm{FeCl}_{3}, \mathrm{MgCl}_{2}, \mathrm{NH}_{4} \mathrm{Cl}, \mathrm{NaClO}\right.$, and $\left.\mathrm{NaClO}_{3}\right)$ and gas $\left(\mathrm{Cl}_{2}, \mathrm{HCl}\right.$, and $\left.\mathrm{CCl}_{4}\right)$. The chlorination of vanadium oxides $\left(\mathrm{V}_{2} \mathrm{O}_{3}\right.$ and $\left.\mathrm{V}_{2} \mathrm{O}_{5}\right)$ by different chlorinating agents was investigated from the thermodynamics. Meanwhile, this paper summarizes the research progress of chlorination in the treatment of vanadium-containing materials. This paper has important reference significance for further adopting the chlorination method to treat vanadium-containing raw materials.
\end{abstract}

Keywords: vanadium; chlorination metallurgy; chlorination agents; $\mathrm{NaCl}$ roasting; carbochlorination; thermodynamics; molten salt chlorination

\section{Introduction}

Vanadium is located in the fourth period and fifth (VB) group of the periodic table and which occupies the 23 rd position in the periodic table of elements. The symbol of the vanadium element is $\mathrm{V}$. The physical characteristics of vanadium are a melting point of $1929^{\circ} \mathrm{C}$, boiling point of $3350{ }^{\circ} \mathrm{C}$, relative atomic mass of 50.9415 , and density of 5.96 $\left(\mathrm{g} / \mathrm{cm}^{3}\right)$, and it is a silver grey metal [1,2]. The valence of vanadium in compounds can be $+2,+3,+4$, and +5 [3]. At present, there are known vanadium oxides such as $\mathrm{V}_{2} \mathrm{O}_{3}$, $\mathrm{VO}_{2}, \mathrm{~V}_{2} \mathrm{O}_{5}, \mathrm{~V}_{3} \mathrm{O}_{5}, \mathrm{~V}_{3} \mathrm{O}_{7}, \mathrm{~V}_{4} \mathrm{O}_{7}, \mathrm{~V}_{5} \mathrm{O}_{9}, \mathrm{~V}_{6} \mathrm{O}_{11}$, and $\mathrm{V}_{6} \mathrm{O}_{13}$, among which the pentavalent vanadium compounds are the most stable [4]. The main chlorides are $\mathrm{VOCl}_{3}, \mathrm{VOCl}, \mathrm{VCl}_{5}$, $\mathrm{VCl}_{4}, \mathrm{VCl}_{3}, \mathrm{VCl}_{2}$, and $\mathrm{VCl}$, among which $\mathrm{VOCl}_{3}$ are the most stable [5]. However, the toxicity of vanadium compounds increases with the increase of vanadium valence, and the pentavalent vanadium compounds are the most toxic. Thus, compounds containing pentavalent vanadium, such as $\mathrm{NaVO}_{3}, \mathrm{NH}_{4} \mathrm{VO}_{3}, \mathrm{~V}_{2} \mathrm{O}_{5}$, and $\mathrm{VOCl}_{3}$, are the most toxic [6]. Toxic vanadium compounds can exist in both cationic and anionic forms [7].

Vanadium as a rare element has a wide range of applications in iron and steel production, vanadium flow batteries, catalysts, etc. [8,9]. The raw materials for the production of vanadium products mainly include vanadium-titanium magnetite, vanadium slag, stone coal, petroleum coke, fly ash, and spent catalysts, etc. $[1,8,9]$. Salt roasting $\left(\mathrm{Na}_{2} \mathrm{CO}_{3}, \mathrm{NaCl}\right.$, $\mathrm{NaOH}, \mathrm{CaO}$, etc.) was applied to extract vanadium from vanadium-containing materials $[1,8,9]$. However, the salt roasting method extraction of vanadium from vanadium slag is associated with the formation of a large amount of sludge and significant losses of vanadium [10]. Previous review articles on vanadium extraction from vanadium-containing 
materials mainly focused on the salt roasting process $[1,8,9]$. In this work, extraction of the rare element vanadium from vanadium-containing materials by chlorination method was summarized.

Table 1 shows melting temperature, boiling temperature, and sublimation temperature for vanadium compounds [11,12]. According to Table 1, the melting point and boiling point of chloride are lower than those of corresponding oxides. Thus, chloride is easier to separate and enrich than oxide [13-15]. Chlorinated metallurgy has a wide range of applications in the treatment of ore, slag, solid wastes, etc. [16-22]. In the last century, the extraction of Ti from titanium ore by chlorination method has been industrialized [23]. Chlorinating agent plays an important role in chlorination metallurgy, which is divided into solid $\left.\left(\mathrm{NaCl}, \mathrm{KCl}, \mathrm{CaCl}_{2}, \mathrm{AlCl}_{3}, \mathrm{FeCl}_{2}, \mathrm{FeCl}_{3}, \mathrm{MgCl}_{2}, \mathrm{NH}_{4} \mathrm{Cl}, \mathrm{NaClO}, \mathrm{NaClO}\right)_{3}\right)$ and gas $\left(\mathrm{Cl}_{2}\right.$, $\mathrm{HCl}, \mathrm{CCl}_{4}$ ) [24-29]. Compared with gaseous chlorinating agents, the solid chlorinating agents are easier to handle and more environmentally friendly.

Table 1. Melting temperature, boiling temperature, and sublimation temperature for vanadium compounds.

\begin{tabular}{cc}
\hline V-O-Cl Substance & Transition Temperature $\left({ }^{\circ} \mathbf{C}\right)$ \\
\hline$V$ & $T_{\mathrm{m}}=1347$ \\
& $\mathrm{~T}_{\mathrm{s}}=1407$ \\
$\mathrm{VCl}_{3}$ & $\mathrm{~T}_{\mathrm{b}}=1530$ \\
$\mathrm{VCl}_{4}$ & $\mathrm{~T}_{\mathrm{s}}=833$ \\
$\mathrm{VOCl}_{3}$ & $\mathrm{~T}_{\mathrm{b}}=151$ \\
$\mathrm{VO}_{2} \mathrm{Cl}$ & $\mathrm{T}_{\mathrm{b}}=127$ \\
$\mathrm{VOCl}_{2}$ & $\mathrm{~T}_{\mathrm{b}}=177$ \\
$\mathrm{VOCl}$ & $\mathrm{T}_{\mathrm{s}}=511$ \\
$\mathrm{VO}$ & $\mathrm{T}_{\mathrm{s}}=1120$ \\
$\mathrm{~V}_{2} \mathrm{O}_{3}$ & $\mathrm{~T}_{\mathrm{m}}=1790$ \\
$\mathrm{VO}_{2}$ & $\mathrm{~T}_{\mathrm{m}}=1970$ \\
$\mathrm{~V}_{2} \mathrm{O}_{5}$ & $\mathrm{~T}_{\mathrm{m}}=1545$ \\
$\mathrm{VO}_{\mathrm{m}}$ & $\mathrm{T}_{\mathrm{m}}=690$ \\
\hline
\end{tabular}

$\mathrm{T}_{\mathrm{m}}$, melting temperature; $\mathrm{T}_{\mathrm{b}}$, boiling temperature; $\mathrm{T}_{\mathrm{s}}$, sublimation temperature.

The traditional chlorination method of extracting vanadium with $\mathrm{NaCl}$ as an additive will produce $\mathrm{NaVO}_{3}$ and then ammonia nitrogen wastewater will be produced in the process of preparing $\mathrm{V}_{2} \mathrm{O}_{5}$. The carbochlorination method of extracting vanadium to prepare $\mathrm{VOCl}_{3}$ will not produce ammonia nitrogen wastewater. Molten salt chlorination of extracting vanadium will obtain $\mathrm{VCl}_{3}$, and metal $\mathrm{V}$ will be obtained by molten salt electrolysis. In this work, these two new processes will be introduced.

\section{Vanadium Reserves and the Major Vanadium Producers}

Table 2 shows the world's vanadium ore reserves in 2018. More than $99 \%$ of the world's vanadium ore reserves are concentrated in China, Russia, South Africa and Australia [30]. Meanwhile, China has the largest vanadium reserves. According to statistics, in 2018, about $16 \%$ of the world's vanadium products directly came from vanadium-titanium magnetite, about $68 \%$ of the vanadium products came from the vanadium-rich steel slag (and a small amount of phosphorus-rich vanadium slag) obtained by vanadium-titanium magnetite after iron and steel metallurgical processing, and approximately $16 \%$ of vanadium products were produced from recovered vanadium-containing by-products (vanadium-containing fuel ash, waste chemical catalysts) and vanadium-containing stone coal [30]. Table 3 shows the overview of major vanadium producers in the world in 2018 [30]. In 2018, the world's total vanadium output calculated in the form of metal vanadium was $91,844 \mathrm{t}$ [30]. The global market share of vanadium products in 2018 was approximately $90.8 \%$ ferroalloy products ( $\mathrm{FeV}, \mathrm{VN}$, ferrovanadium nitride, etc), approximately $4.2 \%$ non-ferrous metals such as $\mathrm{Ti}$, and about $5 \%$ of vanadium compounds (vanadium oxide, ammonium vanadate, $\mathrm{VOSO}_{4}$, etc.) for the chemical industry, energy storage and other fields [30]. Like the consumption pattern of the global vanadium market, more than $90 \%$ of China's vanadium is used in the steel industry in the form of vanadium alloys [30]. 
Table 2. Global vanadium ore reserve calculated by metallic vanadium in 2018 (10 kt) [30].

\begin{tabular}{lccccc}
\hline China & Russia & South Africa & Australia & United States & Brazil \\
\hline 950 & 500 & 350 & 210 & 4.5 & 13 \\
\hline
\end{tabular}

Table 3. Overview of major vanadium producers in the world in 2018 [30].

\begin{tabular}{|c|c|c|c|}
\hline Company Name & $\begin{array}{l}\text { Production Capacity } \\
\qquad\left(\mathrm{V}_{2} \mathrm{O}_{5}\right) / \mathrm{t}\end{array}$ & Products & Raw Material \\
\hline $\begin{array}{l}\text { Ansteel Pangang Group Co., } \\
\text { Ltd. }\end{array}$ & 40,000 & $\begin{array}{c}\mathrm{FeV}, \mathrm{VN}, \\
\text { vanadium oxide, } \\
\mathrm{V}-\mathrm{Al} \text { alloy }\end{array}$ & Vanadium slag \\
\hline $\begin{array}{l}\text { Russian (Evraz) } \\
\text { company }\end{array}$ & 30,000 & $\begin{array}{l}\mathrm{FeV} \text {, vanadium oxide, } \mathrm{V}-\mathrm{Al} \\
\text { alloy, catalyst }\end{array}$ & $\begin{array}{c}\text { Vanadium slag, fly ash, spent } \\
\text { catalyst }\end{array}$ \\
\hline $\begin{array}{l}\text { HBIS Group Chengsteel } \\
\text { company }\end{array}$ & 25,000 & $\begin{array}{c}\text { FeV, VN, } \\
\text { ferrovanadium nitride, } \\
\text { vanadium oxide }\end{array}$ & Vanadium slag \\
\hline $\begin{array}{l}\text { Beijing Jianlong Heavy } \\
\text { Industry Group Co., Ltd. }\end{array}$ & 15,000 & VN, vanadium oxide & Vanadium slag \\
\hline $\begin{array}{c}\text { Austria Treibacher Industrie } \\
\text { AG }\end{array}$ & 13,000 & $\mathrm{~V}_{2} \mathrm{O}_{3}, \mathrm{~V}_{2} \mathrm{O}_{5}, \mathrm{FeV}$ & Vanadium slag \\
\hline $\begin{array}{c}\text { Glencore (Xstrata) } \\
\text { Sichuan Chuanwei Group }\end{array}$ & 12,000 & FeV, vanadium oxide & vanadium-titanium magnetite \\
\hline $\begin{array}{c}\text { Chengyu Vanadium Titanium } \\
\text { Technology Co., Ltd. } \\
\text { Sichuan Desheng Group }\end{array}$ & 12,000 & $\mathrm{~V}_{2} \mathrm{O}_{5}$ & Vanadium slag \\
\hline $\begin{array}{l}\text { Vanadium and } \\
\text { Titanium Co., Ltd. }\end{array}$ & 12,000 & Vanadium slag & Vanadium slag \\
\hline $\begin{array}{l}\text { Largo Resources Ltd. Brazil } \\
\text { Maracás Menchen Mine }\end{array}$ & 11,000 & $\mathrm{~V}_{2} \mathrm{O}_{5}$ & Vanadium-titanium magnetite \\
\hline $\begin{array}{c}\text { Bushveld Vametco, South } \\
\text { Africa }\end{array}$ & 6000 & VN, vanadium oxide & Vanadium-titanium magnetite \\
\hline $\begin{array}{c}\text { Australia Atlantic Vanadium } \\
\text { PTY Ltd. }\end{array}$ & 12,000 & FeV, vanadium oxide & Vanadium-titanium magnetite \\
\hline $\begin{array}{l}\text { Vanchem Vanadium Product } \\
\text { (Pty) Ltd. }\end{array}$ & 10,000 & FeV, vanadium oxide, catalyst & $\begin{array}{c}\text { Vanadium-titanium magnetite, } \\
\text { vanadium slag }\end{array}$ \\
\hline $\begin{array}{c}\text { Czech Republic, Germany, } \\
\text { Canada, Japan, India, Taiwan, } \\
\text { Thailand, etc. }\end{array}$ & 12,000 & $\mathrm{~V}_{2} \mathrm{O}_{5}, \mathrm{~V}-\mathrm{Al}$ alloy, $\mathrm{FeV}$, etc. & $\begin{array}{c}\text { Slag, waste catalyst, fuel ash, } \\
\text { etc. }\end{array}$ \\
\hline $\begin{array}{l}\text { Other Chinese } \\
\text { manufacturers }\end{array}$ & 37,000 & $\mathrm{~V}_{2} \mathrm{O}_{5}, \mathrm{~V}-\mathrm{Al}$ alloy, $\mathrm{VN}, \mathrm{FeV}$, etc. & $\begin{array}{c}\text { Vanadium slag, waste catalyst, } \\
\text { stone coal }\end{array}$ \\
\hline
\end{tabular}

\section{Chlorination Thermodynamics of Vanadium Oxides}

Vanadium in vanadium-titanium magnetite, vanadium slag, and stone coal mainly exists in trivalent form. Meanwhile, the $\mathrm{V}^{5+}$ compounds are the very stable. Thus, $\mathrm{V}_{2} \mathrm{O}_{3}$ and $\mathrm{V}_{2} \mathrm{O}_{5}$ were selected as the reactants for thermodynamic calculation by HSC Chemistry 6.4. The possibilities of $\mathrm{V}_{2} \mathrm{O}_{3}$ reacting with different chlorinating agents are calculated from the thermodynamic viewpoint as shown in Equations (1)-(10). Figure 1 shows the standard Gibbs free energies of reactions between $\mathrm{V}_{2} \mathrm{O}_{3}$ and chlorination agents at $0-1300{ }^{\circ} \mathrm{C} . \mathrm{V}_{2} \mathrm{O}_{3}$ can be chlorinated to $\mathrm{VCl}_{3}$ by $\mathrm{AlCl}_{3}, \mathrm{CCl}_{4}$ and $\mathrm{COCl}_{2}$. Gibbs free energies of reaction between $\mathrm{V}_{2} \mathrm{O}_{3}$ and $\mathrm{AlCl}_{3}$ increases with increasing temperature. Thermodynamically, increasing temperature is not conducive to $\mathrm{AlCl}_{3}$ chlorination. However, $\mathrm{V}_{2} \mathrm{O}_{3}$ cannot be chlorinated to $\mathrm{VCl}_{3}$ by the $\mathrm{NaCl}, \mathrm{CaCl}_{2}, \mathrm{FeCl}_{2}, \mathrm{FeCl}_{3}, \mathrm{MgCl}_{2}, \mathrm{HCl}$ or $\mathrm{Cl}_{2}$ at $0-1300{ }^{\circ} \mathrm{C}$.

$$
\begin{aligned}
& \mathrm{V}_{2} \mathrm{O}_{3}+6 \mathrm{NaCl}=2 \mathrm{VCl}_{3}+3 \mathrm{Na}_{2} \mathrm{O} \\
& \mathrm{V}_{2} \mathrm{O}_{3}+3 \mathrm{CaCl}_{2}=2 \mathrm{VCl}_{3}+3 \mathrm{CaO} \\
& \mathrm{V}_{2} \mathrm{O}_{3}+3 \mathrm{FeCl}_{2}=2 \mathrm{VCl}_{3}+3 \mathrm{FeO}
\end{aligned}
$$




$$
\begin{gathered}
\mathrm{V}_{2} \mathrm{O}_{3}+2 \mathrm{FeCl}_{3}=2 \mathrm{VCl}_{3}+\mathrm{Fe}_{2} \mathrm{O}_{3} \\
\mathrm{~V}_{2} \mathrm{O}_{3}+2 \mathrm{AlCl}_{3}=2 \mathrm{VCl}_{3}+\mathrm{Al}_{2} \mathrm{O}_{3} \\
\mathrm{~V}_{2} \mathrm{O}_{3}+3 \mathrm{MgCl}=2 \mathrm{VCl}_{3}+3 \mathrm{MgO} \\
\mathrm{V}_{2} \mathrm{O}_{3}+6 \mathrm{HCl}(\mathrm{g})=2 \mathrm{VCl}_{3}+3 \mathrm{H}_{2} \mathrm{O}(\mathrm{g}) \\
\mathrm{V}_{2} \mathrm{O}_{3}+3 \mathrm{Cl}_{2}(\mathrm{~g})=2 \mathrm{VCl}_{3}+1.5 \mathrm{O}_{2}(\mathrm{~g}) \\
\mathrm{V}_{2} \mathrm{O}_{3}+1.5 \mathrm{CCl}_{4}(\mathrm{~g})=2 \mathrm{VCl}_{3}+1.5 \mathrm{CO}_{2}(\mathrm{~g}) \\
\mathrm{V}_{2} \mathrm{O}_{3}+3 \mathrm{COCl}_{2}(\mathrm{~g})=2 \mathrm{VCl}_{3}+3 \mathrm{CO}_{2}(\mathrm{~g})
\end{gathered}
$$



Figure 1. The standard Gibbs free energies of reactions between $\mathrm{V}_{2} \mathrm{O}_{3}$ and chlorination agents (reactions 1-10).

The $\mathrm{V}_{2} \mathrm{O}_{5}$ reacting with different chlorinating agents are as follows: Equations (11)-(20). Figure 2 shows the standard Gibbs free energies of reactions between $\mathrm{V}_{2} \mathrm{O}_{5}$ and chlorination agents. $\mathrm{V}_{2} \mathrm{O}_{5}$ can be chlorinated to $\mathrm{VOCl}_{3}$ by $\mathrm{FeCl}_{3}, \mathrm{AlCl}_{3}, \mathrm{CCl}_{4}$ and $\mathrm{COCl}_{2}$ at $0-1300{ }^{\circ} \mathrm{C}$. However, $\mathrm{V}_{2} \mathrm{O}_{3}$ cannot be chlorinated to $\mathrm{VOCl}_{3}$ by the $\mathrm{NaCl}, \mathrm{CaCl}_{2}, \mathrm{FeCl}_{2}, \mathrm{MgCl}_{2}, \mathrm{HCl}$ and $\mathrm{Cl}_{2}$ at $0-1300{ }^{\circ} \mathrm{C}$.

$$
\begin{gathered}
\mathrm{V}_{2} \mathrm{O}_{5}+6 \mathrm{NaCl}=2 \mathrm{VOCl}_{3}(\mathrm{~g})+3 \mathrm{Na}_{2} \mathrm{O} \\
\mathrm{V}_{2} \mathrm{O}_{5}+3 \mathrm{CaCl}_{2}=2 \mathrm{VOCl}_{3}+3 \mathrm{CaO} \\
\mathrm{V}_{2} \mathrm{O}_{5}+3 \mathrm{MgCl}_{2}=2 \mathrm{VOCl}_{3}+3 \mathrm{MgO} \\
\mathrm{V}_{2} \mathrm{O}_{5}+3 \mathrm{FeCl}_{2}=2 \mathrm{VOCl}_{3}+3 \mathrm{FeO} \\
\mathrm{V}_{2} \mathrm{O}_{5}+2 \mathrm{FeCl}_{3}=2 \mathrm{VOCl}_{3}+\mathrm{Fe}_{2} \mathrm{O}_{3} \\
\mathrm{~V}_{2} \mathrm{O}_{5}+2 \mathrm{AlCl}_{3}=2 \mathrm{VOCl}_{3}+\mathrm{Al}_{2} \mathrm{O}_{3} \\
\mathrm{~V}_{2} \mathrm{O}_{5}+6 \mathrm{HCl}(\mathrm{g})=2 \mathrm{VOCl}_{3}+3 \mathrm{H}_{2} \mathrm{O}(\mathrm{g}) \\
\mathrm{V}_{2} \mathrm{O}_{5}+3 \mathrm{COCl}_{2}(\mathrm{~g})=2 \mathrm{VOCl}_{3}+3 \mathrm{CO}_{2}(\mathrm{~g}) \\
\mathrm{V}_{2} \mathrm{O}_{5}+1.5 \mathrm{CCl}_{4}(\mathrm{~g})=2 \mathrm{VOCl}_{3}+1.5 \mathrm{CO}_{2}(\mathrm{~g}) \\
\mathrm{V}_{2} \mathrm{O}_{5}+3 \mathrm{Cl}_{2}(\mathrm{~g})=2 \mathrm{VOCl}_{3}+1.5 \mathrm{O}_{2}(\mathrm{~g})
\end{gathered}
$$

The $\mathrm{V}_{2} \mathrm{O}_{5}$ and $\mathrm{V}_{2} \mathrm{O}_{3}$ reacting with $\mathrm{C}$ and $\mathrm{Cl}_{2}$ in the temperature range from $0{ }^{\circ} \mathrm{C}$ to $1300{ }^{\circ} \mathrm{C}$ are expressed as follows in Equations (21) and (22). Figure 3 shows standard Gibbs free energies of reactions $21-22$ at $0-1300{ }^{\circ} \mathrm{C}$. Adding $\mathrm{C}$ realizes the chlorination of $\mathrm{V}_{2} \mathrm{O}_{5}$ 
and $\mathrm{V}_{2} \mathrm{O}_{3}$ to $\mathrm{VOCl}_{3}$ by $\mathrm{Cl}_{2}$ at $0-1300{ }^{\circ} \mathrm{C}$. However, the effect of increasing temperature on the chlorination of $\mathrm{V}_{2} \mathrm{O}_{3}$ and $\mathrm{V}_{2} \mathrm{O}_{5}$ is opposite.

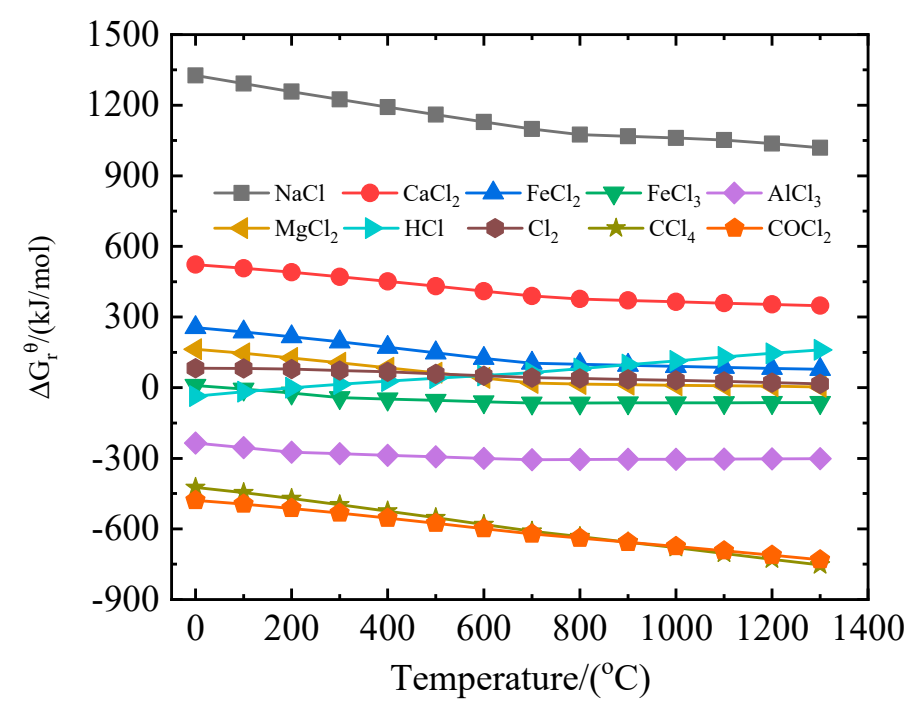

Figure 2. The standard Gibbs free energies of reactions between $\mathrm{V}_{2} \mathrm{O}_{5}$ and chlorination agents (reactions 11-20).

$$
\begin{gathered}
2 \mathrm{~V}_{2} \mathrm{O}_{3}+6 \mathrm{Cl}_{2}(\mathrm{~g})+\mathrm{C}=4 \mathrm{VOCl}_{3}+\mathrm{CO}_{2}(\mathrm{~g}) \\
\mathrm{V}_{2} \mathrm{O}_{5}+3 \mathrm{Cl}_{2}(\mathrm{~g})+1.5 \mathrm{C}=2 \mathrm{VOCl}_{3}+1.5 \mathrm{CO}_{2}(\mathrm{~g})
\end{gathered}
$$

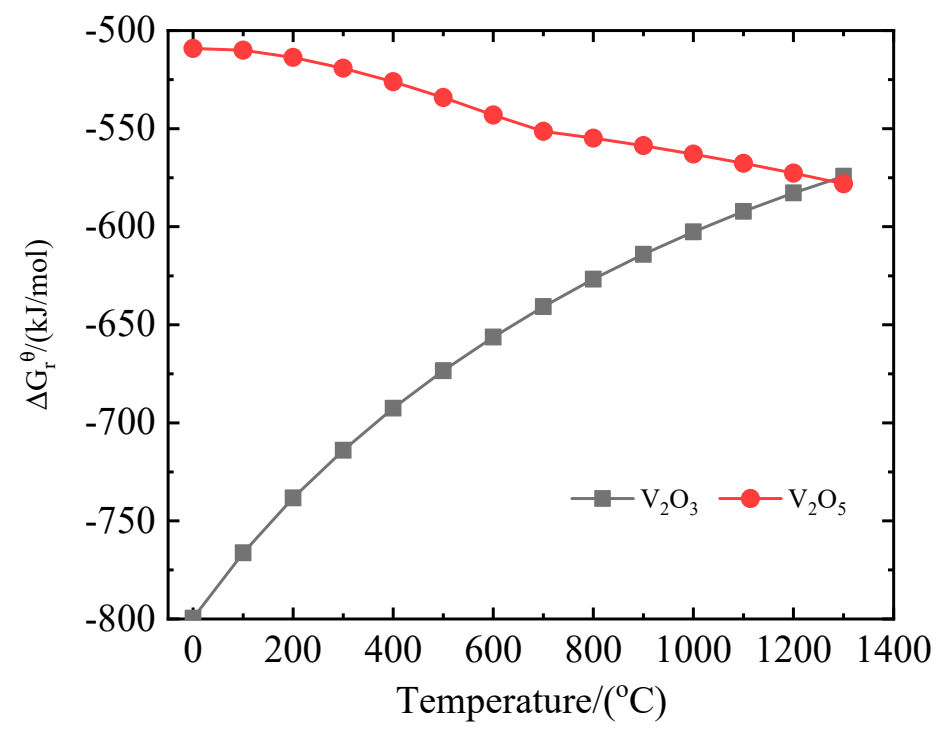

Figure 3. Variation of standard Gibbs free energy of reactions 21-22 with temperature.

Under an oxygen atmosphere, the equations for the $\mathrm{NaCl}$ roasting reaction of $\mathrm{V}_{2} \mathrm{O}_{3}$ and $\mathrm{V}_{2} \mathrm{O}_{5}$ are as shown in Equations (23) and (24). Figure 4 shows the variation of standard Gibbs free energy of reactions 23-24 with temperature. Under the same conditions, $\mathrm{V}_{2} \mathrm{O}_{3}$ is more easily chlorinated. Thermodynamically, increasing temperature is not conducive to $\mathrm{NaCl}$ chlorination of $\mathrm{V}_{2} \mathrm{O}_{3}$. The reaction of $\mathrm{V}_{2} \mathrm{O}_{3}$ and different chlorinating agents $\left(\mathrm{FeCl}_{2}\right.$ and $\mathrm{FeCl}_{3}$ ) are as shown in Equations (25) and (26). It can be seen from Figure 4 that $\mathrm{V}_{2} \mathrm{O}_{3}$ can be chlorinated by $\mathrm{FeCl}_{2}$ and $\mathrm{FeCl}_{3}$ under an oxygen atmosphere.

$$
\mathrm{V}_{2} \mathrm{O}_{3}+2 \mathrm{NaCl}+1.5 \mathrm{O}_{2}(\mathrm{~g})=2 \mathrm{NaVO}_{3}+\mathrm{Cl}_{2}(\mathrm{~g})
$$




$$
\begin{gathered}
2 \mathrm{~V}_{2} \mathrm{O}_{5}+4 \mathrm{NaCl}+\mathrm{O}_{2}(\mathrm{~g})=4 \mathrm{NaVO}_{3}+2 \mathrm{Cl}_{2}(\mathrm{~g}) \\
\mathrm{V}_{2} \mathrm{O}_{3}+2 \mathrm{FeCl}_{3}+\mathrm{O}_{2}(\mathrm{~g})=2 \mathrm{VOCl}_{3}(\mathrm{~g})+\mathrm{Fe}_{2} \mathrm{O}_{3} \\
\mathrm{~V}_{2} \mathrm{O}_{3}+3 \mathrm{FeCl}_{2}+1.75 \mathrm{O}_{2}(\mathrm{~g})=2 \mathrm{VOCl}_{3}(\mathrm{~g})+1.5 \mathrm{Fe}_{2} \mathrm{O}_{3}
\end{gathered}
$$

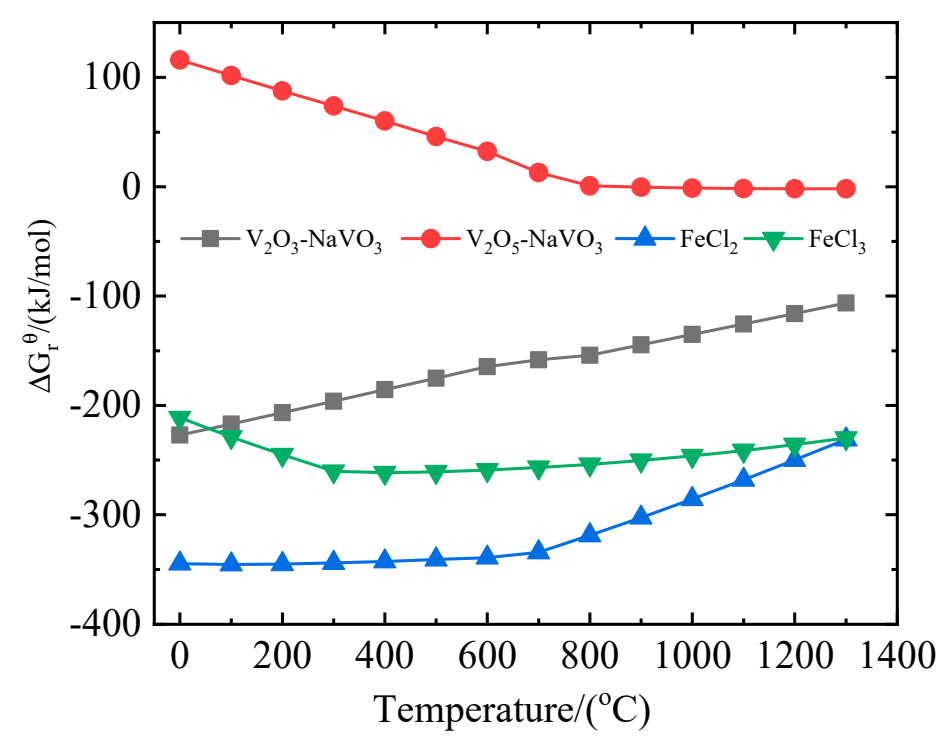

Figure 4. Variation of standard Gibbs free energy of reactions 23-26 with temperature.

According to the above thermodynamic analysis, the valence state of vanadium, reaction temperature, atmosphere and chlorinating agent play a very important role in the chlorination of vanadium. Thus, the chlorination of vanadium can be achieved by selecting appropriate conditions. The following will introduce the progress of chlorination of vanadium-containing materials.

\section{Application of Chlorination Method}

\subsection{Chlorination Extraction of Vanadium from Vanadium Titanomagnetite}

Vanadium-titanium magnetite is mainly composed of iron (Fe), vanadium $(\mathrm{V})$ and titanium (Ti) elements, which is multi-element symbiotic iron ore containing a small amount of cobalt (Co), nickel (Ni), chromium (Cr), scandium (Sc) and gallium (Ga) [31,32]. The reserves of vanadium-titanium magnetite in the Panzhihua-Xichang regions in China amount to about 9.66 billion tons [33]. The content of vanadium pentoxide in vanadiumtitanium magnetite is $0.1 \mathrm{wt} \%-2 \mathrm{wt} \%$ [34]. Jena et al. [23] proposed that under the action of oxygen and water, $\mathrm{NaCl}$ as an additive reacts with the vanadium in the vanadium bearing titaniferrous magnetite. The roasted samples were leached with hot water. More than $90 \%$ of $\mathrm{V}$ was extracted. The reaction Equations are as follows in Equations (27)-(31).

$$
\begin{gathered}
\mathrm{SiO}_{2}+2 \mathrm{NaCl}+\mathrm{H}_{2} \mathrm{O}=\mathrm{Na}_{2} \mathrm{SiO}_{3}+2 \mathrm{HCl} \\
\mathrm{Na}_{2} \mathrm{SiO}_{3}+\mathrm{O}_{2}+\mathrm{V}_{2} \mathrm{O}_{3}=2 \mathrm{NaVO}_{3}+\mathrm{SiO}_{2} \\
2 \mathrm{NaCl}+3 / 2 \mathrm{O}_{2}+\mathrm{V}_{2} \mathrm{O}_{3}=2 \mathrm{NaVO}_{3}+\mathrm{Cl}_{2} \\
3 \mathrm{Cl}_{2}+3 \mathrm{~V}_{2} \mathrm{O}_{3}=2 \mathrm{VOCl}_{3}+2 \mathrm{~V}_{2} \mathrm{O}_{5} \\
4 \mathrm{VOCl}_{3}+3 \mathrm{O}_{2}=2 \mathrm{~V}_{2} \mathrm{O}_{5}+6 \mathrm{Cl}_{2}
\end{gathered}
$$

To some extent, the presence of $\mathrm{SiO}_{2}$ and the formation of $\mathrm{HCl}$ and $\mathrm{Cl}_{2}$ can promote the extraction of vanadium [23,35,36]. Zheng et al. [37] first calculated the feasibility of extraction vanadium from vanadium-rich resources with $\mathrm{FeCl}_{2}$ and $\mathrm{FeCl}_{3}$. Thermodynamic calculations show that the higher the valence of vanadium in vanadium titanomagnetite, 
the easier it is to extract vanadium. Therefore, the chlorinated atmosphere was selected as the oxygen atmosphere. The reaction Equations are as follows in Equations (32)-(36). Under the optimal experimental conditions $\left(827^{\circ} \mathrm{C}\right.$, reactant (vanadium titanomagnetite)chlorination agent $\left(\mathrm{FeCl}_{3}\right)$ molar ratio of $1: 2,2 \mathrm{~h}$, oxygen atmosphere), the extraction ratio of vanadium is $32 \%$.

$$
\begin{gathered}
\mathrm{V}_{2} \mathrm{O}_{5}+2 \mathrm{FeCl}_{3}=\mathrm{VOCl}_{3}+\mathrm{Fe}_{2} \mathrm{O}_{3} \\
2 \mathrm{~V}_{2} \mathrm{O}_{4}+4 \mathrm{FeCl}_{3}+\mathrm{O}_{2}=4 \mathrm{VOCl}_{3}+2 \mathrm{Fe}_{2} \mathrm{O}_{3} \\
2 \mathrm{~V}_{2} \mathrm{O}_{3}+4 \mathrm{FeCl}_{3}+(2 x-1) \mathrm{O}_{2}=4 \mathrm{VOCl}_{3}+4 \mathrm{FeO}_{x} \\
\mathrm{~V}_{2} \mathrm{O}_{4}+\mathrm{FeCl}_{3}+(x-1) \mathrm{O}_{2}=\mathrm{VOCl}_{3}+\mathrm{FeO}_{x} \\
12 \mathrm{FeCl}_{2}+4 \mathrm{~V}_{2} \mathrm{O}_{5}+3 \mathrm{O}_{2}=6 \mathrm{Fe}_{2} \mathrm{O}_{3}+8 \mathrm{VOCl}_{3}
\end{gathered}
$$

Chloride extraction of vanadium from vanadium-titanium magnetite has long been used. However, the content of vanadium in vanadium-titanium magnetite is low, and the cost of directly extracting vanadium in vanadium slag using chlorination method is high. Thus, it is not recommended to extract vanadium directly from vanadium-titanium magnetite by chlorination method.

\subsection{Chlorination Extraction of Vanadium from Vanadium Slag}

Vanadium slag is produced from vanadium-titanium magnetite by blast furnace smelting and the vanadium extraction process in a converter [38,39]. Vanadium slags contain 30-40 wt\% total $\mathrm{Fe}, 6.9-14.4 \mathrm{wt} \% \mathrm{TiO}_{2}, 13.5-19.0 \mathrm{wt} \% \mathrm{~V}_{2} \mathrm{O}_{3}, 0.9-4.6 \mathrm{wt} \% \mathrm{Cr}_{2} \mathrm{O}_{3}$, and 7.4-10.7 $\mathrm{wt} \% \mathrm{MnO}$. The main phases of vanadium slag consist of $(\mathrm{Fe}, \mathrm{Mn})(\mathrm{V}, \mathrm{Cr})_{2} \mathrm{O}_{4}$, $(\mathrm{Fe}, \mathrm{Mn})_{2} \mathrm{SiO}_{4}$ and $\mathrm{Fe}_{2} \mathrm{TiO}_{4}$. According to the phases of vanadium slag, vanadium is present in the form of $\mathrm{V}^{3+}$, from which it is difficult to extract vanadium by direct leaching $[40,41]$.

In order to extract vanadium, the traditional method is to oxidize insoluble low-valent vanadium to soluble high-valent vanadium in aqueous solution $[42,43]$. Figure 5 shows a flow chart of extracting vanadium from vanadium slag by $\mathrm{NaCl}$ roasting. The roasting temperature is about $800^{\circ} \mathrm{C}$. After roasting, vanadium in the solid exists in the form of $\mathrm{NaVO}_{3}$, and then dissolves to obtain $\mathrm{NaVO}_{3}$ solution. Vanadium is precipitated in the form of ammonium vanadate by adding ammonium salt $\left(\mathrm{NH}_{4} \mathrm{Cl}, \mathrm{NH}_{4} \mathrm{HCO}_{3},\left(\mathrm{NH}_{4}\right)_{2} \mathrm{SO}_{4}\right.$, $\left.\left(\mathrm{NH}_{4}\right)_{2} \mathrm{CO}_{3}\right)$. Ammonium vanadate is calcined to obtain $\mathrm{V}_{2} \mathrm{O}_{5}$ at about $550{ }^{\circ} \mathrm{C}$. Under the action of oxygen, $\mathrm{NaCl}$ as an additive reacts with the vanadium spinel in the vanadium slag. The reaction Equation is as follows in Equation (37). The conversion rate of vanadium can reach $85 \%[44,45]$.

$$
4 \mathrm{FeV}_{2} \mathrm{O}_{4}+8 \mathrm{NaCl}+7 \mathrm{O}_{2}=8 \mathrm{NaVO}_{3}+4 \mathrm{Cl}_{2}+2 \mathrm{Fe}_{2} \mathrm{O}_{3}
$$

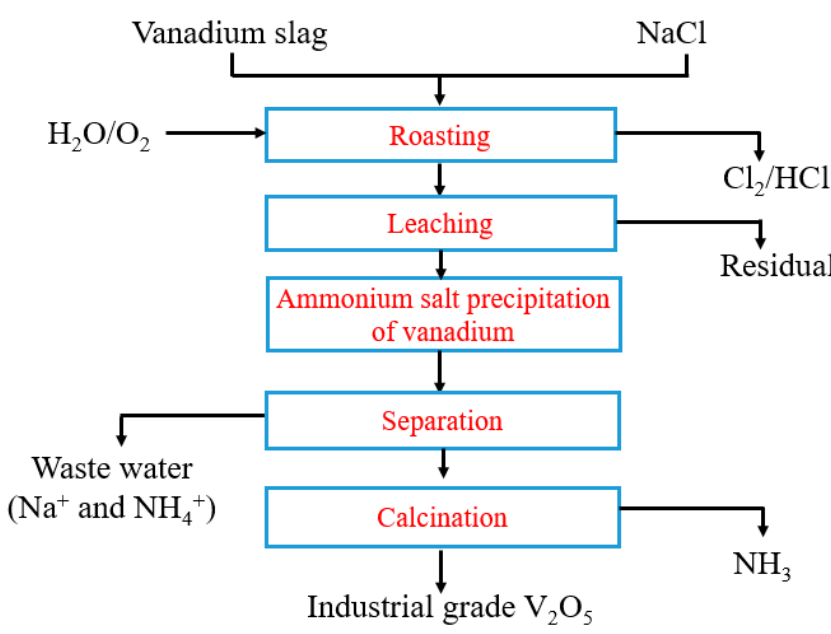

Figure 5. Flow chart of extracting vanadium from vanadium slag by $\mathrm{NaCl}$ roasting. 
A total of $85.8 \%$ of $\mathrm{V}$ in vanadium slag was extracted by acidic sodium chlorate solution. $\mathrm{V}^{3+}$ in vanadium slag was oxidized by $\mathrm{NaClO}_{3}$ as a chlorinating agent. The reaction Equation is as follows in Equation (38) [46].

$$
6 \mathrm{FeV}_{2} \mathrm{O}_{4}+5 \mathrm{NaClO}_{3}+15 \mathrm{H}_{2} \mathrm{SO}_{4}=5 \mathrm{NaCl}+6\left(\mathrm{VO}_{2}\right)_{2} \mathrm{SO}_{4}+3 \mathrm{Fe}_{2}\left(\mathrm{SO}_{4}\right)_{3}+15 \mathrm{H}_{2} \mathrm{O}
$$

Sun et al. [47] proposed chlorination of vanadium slag by $\mathrm{FeCl}_{3}$. Under the optimal experimental conditions $\left(827^{\circ} \mathrm{C}\right.$, reactant (vanadium slag) — chlorination agent $\left(\mathrm{FeCl}_{3}\right)$ molar ratio of 1:2, $2 \mathrm{~h}$, oxygen atmosphere), the extraction ratio of vanadium in vanadium slag is 57\%. Du [48] investigated carbochlorination of pre-oxidized vanadium slag. The flow chart of extracting vanadium from vanadium slag by chlorination is shown in Figure 6. The carbochlorination temperature is about $650{ }^{\circ} \mathrm{C}$. Vanadium is volatile in the form of $\mathrm{VOCl}_{3}$. $\mathrm{VOCl}_{3}$ was oxidized to $\mathrm{V}_{2} \mathrm{O}_{5}$ by $\mathrm{O}_{2}$. The equations of the main reactions involved are (39)-(41). The effect of time, temperature, petroleum coke and chlorine pressure fraction were studied. Under optimal process conditions $\left(650{ }^{\circ} \mathrm{C}, 120 \mathrm{~min}, \mathrm{P}\left(\mathrm{Cl}_{2}\right) / \mathrm{P}\left(\mathrm{Cl}_{2}+\mathrm{N}_{2}\right)=\right.$ $0.5,10 \%$ of petroleum coke mass fraction), $18.8 \%$ of $\mathrm{Fe}$ and $87.5 \%$ of $\mathrm{V}$ were extracted. Wastewater containing high $\mathrm{Na}^{+}$and $\mathrm{NH}_{4}{ }^{+}$is scarcely produced in whole process.

$$
\begin{aligned}
(\mathrm{Fe}, \mathrm{Mn})(\mathrm{V}, \mathrm{Cr}, \mathrm{Ti})_{2} \mathrm{O}_{4}(\mathrm{~s})+\mathrm{O}_{2}(\mathrm{~g}) \rightarrow \mathrm{Fe}_{2} \mathrm{O}_{3}(\mathrm{~s})+\mathrm{MnO}(\mathrm{s})+\mathrm{Cr}_{2} \mathrm{O}_{3}(\mathrm{~s})+\mathrm{V}_{2} \mathrm{O}_{5}(\mathrm{~s})+\mathrm{TiO}_{2}(\mathrm{~s}) \\
1 / 3 \mathrm{~V}_{2} \mathrm{O}_{5}(\mathrm{~s} / \mathrm{l})+1 / 2 \mathrm{C}(\mathrm{s})+\mathrm{Cl}_{2}(\mathrm{~g}) \rightarrow 2 / 3 \mathrm{VOCl}_{3}(\mathrm{~g})+1 / 2 \mathrm{CO}_{2}(\mathrm{~g}) \\
1 / 3 \mathrm{Fe}_{2} \mathrm{O}_{3}(\mathrm{~s})+1 / 2 \mathrm{C}(\mathrm{s})+\mathrm{Cl}_{2}(\mathrm{~g}) \rightarrow 2 / 3 \mathrm{FeCl}_{3}(\mathrm{~g})+1 / 2 \mathrm{CO}_{2}(\mathrm{~g})
\end{aligned}
$$

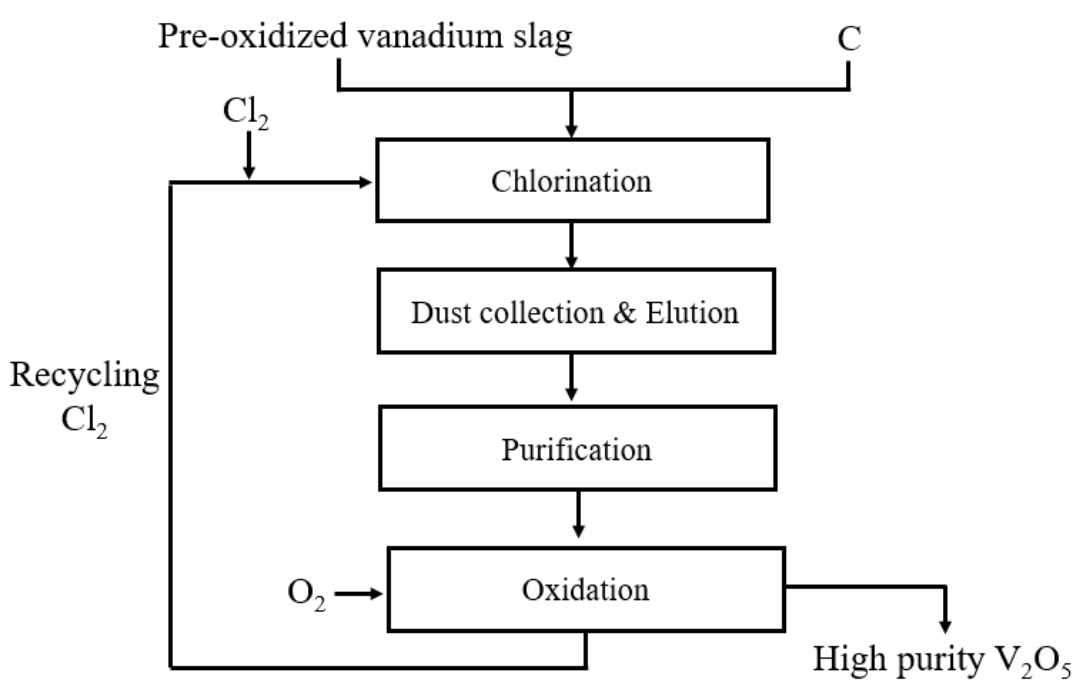

Figure 6. Flow chart of extracting vanadium from vanadium slag by carbochlorination.

In order to extract vanadium from vanadium slag, Liu et al. [49-55] proposed to use selective chlorination method to extract vanadium. Because to the existence form and value of valuable metal elements ( $\mathrm{Fe}, \mathrm{Mn}, \mathrm{V}, \mathrm{Cr}$ and $\mathrm{Ti}$ ) in vanadium slag, $\mathrm{NH}_{4} \mathrm{Cl}$ was selected to chlorinate $\mathrm{Fe}$ and $\mathrm{Mn}$ in vanadium slag. Thermodynamic calculations show that the iron and manganese in vanadium slag could be chlorinated by hydrogen chloride, but the $\mathrm{V}, \mathrm{Cr}$ and Ti could not be chlorinated in the temperature range from 0 to $1000^{\circ} \mathrm{C}$. Under optimal chlorination conditions, the chlorination ratio of iron and manganese were $72 \%$ and $95 \%$, respectively. Meanwhile, the enrichment ratio of $\mathrm{V}, \mathrm{Cr}$ and Ti was obtained as $48 \%$. In addition, $\mathrm{AlCl}_{3}$ was selected to chlorinate $\mathrm{V}, \mathrm{Cr}$ and $\mathrm{Ti}$ in vanadium slag. Figure 7 shows a flow chart of extracting vanadium from vanadium slag by $\mathrm{AlCl}_{3}$ chlorination. The chlorination temperature is about $900{ }^{\circ} \mathrm{C}$. Vanadium after chlorination exists in the form of $\mathrm{VCl}_{3}$. Metal $\mathrm{V}$ was obtained by molten salt electrolysis at $900{ }^{\circ} \mathrm{C}$. The effects of reaction temperature, reaction time, mass ratio of $\mathrm{AlCl}_{3} / \mathrm{slag}$ and mass ratio of salt $/ \mathrm{AlCl}_{3}$ on the chlorination ratio of valuable elements were investigated. Under optimal chlorination 
conditions $\left(\mathrm{AlCl}_{3}\right.$ —slag mass ratio of $1.5: 1,(\mathrm{NaCl}-\mathrm{KCl})-\mathrm{AlCl}_{3}$ mass ratio of $1.66: 1$, at $900{ }^{\circ} \mathrm{C}$, $8 \mathrm{~h}$.), the chlorination ratio of iron, vanadium, chromium and manganese were $90.3 \%$, $76.5 \%, 81.9 \%$ and $97.3 \%$. The volatilization ratio of titanium was $79.9 \%$. The results of kinetic study indicate that the rate-control step of vanadium chlorination process was the surface chemical reaction. The vanadium and chromium in vanadium slag after $\mathrm{AlCl}_{3}$ chlorination were present in the form of $\mathrm{VCl}_{3}$ and $\mathrm{CrCl}_{3}$ in molten salt. The main reaction was as follow (42).

$$
8 \mathrm{AlCl}_{3}+3 \mathrm{FeV}_{2} \mathrm{O}_{4}=3 \mathrm{FeCl}_{2}+4 \mathrm{Al}_{2} \mathrm{O}_{3}+6 \mathrm{VCl}_{3}
$$

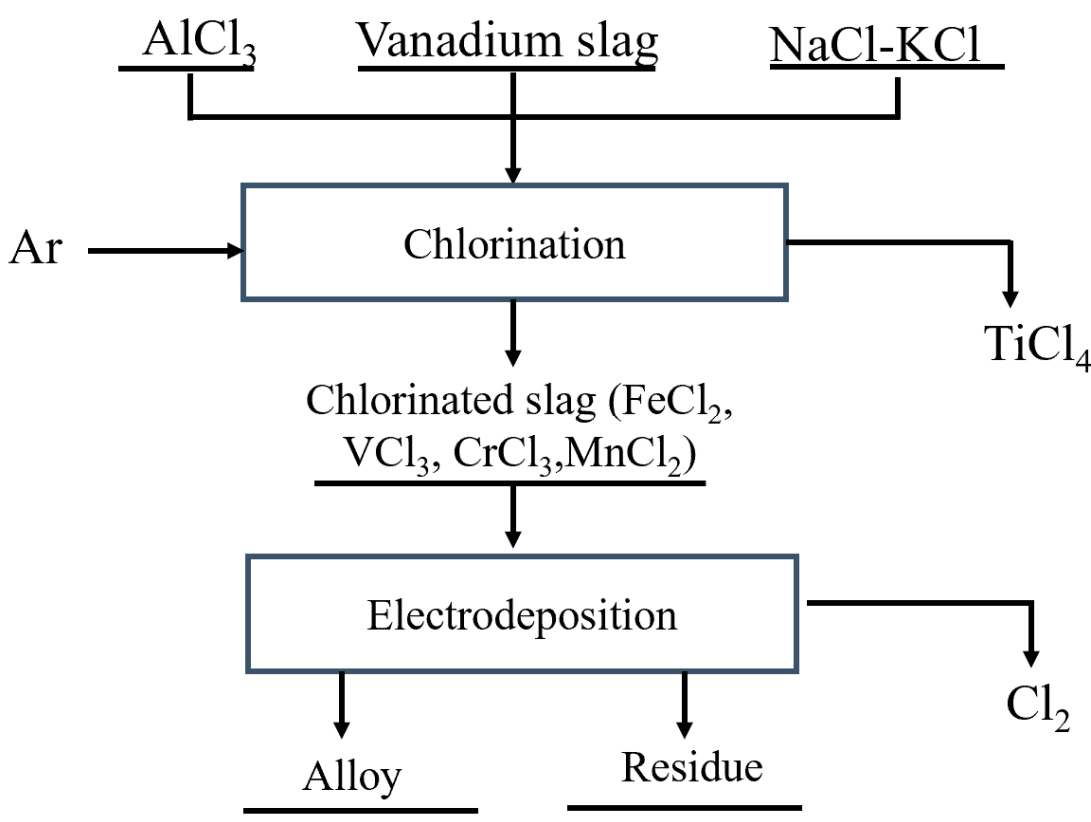

Figure 7. Flow chart of extracting vanadium from vanadium slag by $\mathrm{AlCl}_{3}$ chlorination.

\subsection{Chlorination Extraction of Vanadium from BOF-Slag}

The basic oxygen furnace (BOF)-slags contains $31-56 \% \mathrm{CaO}, 10-27 \% \mathrm{SiO}_{2}, 1-4.5 \%$ $\mathrm{Al}_{2} \mathrm{O}_{3}, 5-35 \% \mathrm{Fe}$ compounds, and less than $1 \%$ of vanadium [56]. Seron et al. investigated the recovery of vanadium from BOF-slags by oxy-carbochlorination. Under specific conditions $\left(900{ }^{\circ} \mathrm{C}\right.$, chlorine partial pressure $0.2,90 \mathrm{~min}, 50 \%$ carbon content), the recovery ratio of vanadium in slag can reach $95 \%$ [57].

\subsection{Chlorination Extraction of Vanadium from Stone Coal}

Black shale is one of China's most important vanadium resources, accounting for more than $87 \%$ of domestic vanadium reserves [58,59]. It is estimated that the reserves of vanadium in the form of $\mathrm{V}_{2} \mathrm{O}_{5}$ in stone coal are 118 million tons [60]. However, the ordinary grade of vanadium in black shale is usually below $2 \mathrm{wt} \%$ [58,59]. In China, vanadium in most of the stone coal replaces trivalent aluminum in mica minerals in a quasihomogeneous form. The chemical formula of vanadium-containing illite is $\mathrm{K}(\mathrm{Al}, \mathrm{V})_{2}(\mathrm{OH})_{2}$ $\left[\mathrm{Si}_{3} \mathrm{Al} \mathrm{O}_{10}\right.$. The mica mineral structure is very stable. It is difficult to destroy the lattice structure by general concentration of acid and alkali. Thus, in order to extract vanadium from vanadium-containing mica, the lattice structure of vanadium containing mica first needs to be destroyed [61].

Under the action of oxygen and water, $\mathrm{NaCl}$ as an additive reacts with the predecarburized stone coal $[62,63]$. The reaction Equation is expressed as follow (43): 
where $\mathrm{m}$ is the number of vanadium ions replacing aluminum ions in hydromica octahedron.

$\mathrm{NaCl}$ has a melting point of $801^{\circ} \mathrm{C}$, which tends to keep the structure stable and does not decompose at high temperature. However, due to the presence of $\mathrm{V}, \mathrm{Al}, \mathrm{Fe}$, and other oxides in the stone coal, $\mathrm{NaCl}$ can be decomposed at lower temperature to generate $\mathrm{Cl}_{2}$ with high chemical reactivity. The reaction is described as follows in Equations (44)-(47). $\mathrm{Cl}_{2}$ can react with low-valent vanadium to form $\mathrm{VOCl}_{3}$, and $\mathrm{VOCl}_{3}$ is an intermediate product that can be further oxidized to $\mathrm{V}_{2} \mathrm{O}_{5}$. The presence of $\mathrm{Cl}_{2}$ promotes the high temperature roasting to destroy the crystal structure of illite. The oxidation of the exposed trivalent vanadium changes to a higher valence state. $\mathrm{Cl}_{2}$ is more active than oxygen at high temperature and is more easily adsorbed on the surface of minerals. The promotion of $\mathrm{Cl}_{2}$ on the oxidation of low-cost vanadium cannot be ignored. Thus, $\mathrm{NaCl}$ as an additives agent was selected for extracting vanadium from stone coal [63-66].

$$
\begin{gathered}
4 \mathrm{NaCl}+\mathrm{O}_{2}=2 \mathrm{Na}_{2} \mathrm{O}+2 \mathrm{Cl}_{2} \\
3 \mathrm{Cl}_{2}+3 \mathrm{~V}_{2} \mathrm{O}_{3}=2 \mathrm{VOCl}_{3}+2 \mathrm{~V}_{2} \mathrm{O}_{5} \\
4 \mathrm{VOCl}_{3}+3 \mathrm{O}_{2}=2 \mathrm{~V}_{2} \mathrm{O}_{5}+6 \mathrm{Cl}_{2} \\
\mathrm{xNa} \mathrm{Na}_{2} \mathrm{y} \mathrm{y}_{2} \mathrm{O}_{5}=\mathrm{xNa} \mathrm{Na}_{2} \mathrm{O} \mathrm{y}_{2} \mathrm{O}_{5}
\end{gathered}
$$

The possible chemical reaction between vanadium oxide $\left(\mathrm{V}_{2} \mathrm{O}_{3}, \mathrm{VO}_{2}\right.$, and $\left.\mathrm{V}_{2} \mathrm{O}_{5}\right)$ and the solid chlorinating agent $\left(\mathrm{NaCl}, \mathrm{CaCl}_{2}\right.$ and $\left.\mathrm{FeCl}_{3}\right)$ was calculated by FactSage 7.1 (Montreal, Canada) using the database of FactPS, FToxid and FT salt. The results show that vanadium oxide cannot be directly chlorinated thermodynamically by $\mathrm{NaCl}$ and $\mathrm{CaCl}_{2}$ as solid chlorinating agents. However, $\mathrm{V}_{2} \mathrm{O}_{4}$ and $\mathrm{V}_{2} \mathrm{O}_{5}$ can be chlorinated by $\mathrm{FeCl}_{3}$. Meanwhile, $\mathrm{V}$ can be separated from black shale by controlled roasting temperature of chlorination volatilization [67]. In the air, the structure of illite and muscovite in stone coal is hard to be destroyed by roasting without additives. Zhang et al. [68] studied that the vanadium-bearing stone coal was roasted in chlorine, and $90 \%$ of $\mathrm{V}$ in the form of $\mathrm{VOCl}_{3}$ was extracted at $1000{ }^{\circ} \mathrm{C}$ for $1 \mathrm{~h}$. Li et al. [69] investigated extraction of vanadium by leaching. Under the optimal leaching conditions (liquid-to-solid ratio of 2, oxygen partial pressure of $1200 \mathrm{kPa}, 90^{\circ} \mathrm{C}, 6 \mathrm{~h}, 1.5 \mathrm{~g} / \mathrm{L} \mathrm{NaClO}, 15 \mathrm{~g} / \mathrm{L} \mathrm{HF}, 100 \mathrm{~g} / \mathrm{L} \mathrm{H}_{2} \mathrm{SO}_{4}$ ), $91 \%$ of $\mathrm{V}$ in vanadium slag was extracted by $\mathrm{NaClO}-\mathrm{H}_{2} \mathrm{SO}_{4}-\mathrm{HF}$ system under atmospheric pressure. $\mathrm{V}^{3+}$ in stone was oxidized by $\mathrm{NaClO}$ as a chlorinating agent and oxidant.

\subsection{Chlorination Extraction of Vanadium from Spent Catalysts}

Catalysts are extensively used in sulfuric acid production and petroleum refining [70,71]. More than 100,000 tons of spent hydrodesulphurization catalysts are produced every year, which usually contain the valuable elements $\mathrm{V}, \mathrm{Mo}, \mathrm{Ni}$, and $\mathrm{Co}$ [72]. Vanadium in spent catalyst is present in the form of sulfide $\left(\mathrm{V}_{2} \mathrm{~S}_{3}\right.$ or $\left.\mathrm{V}_{3} \mathrm{~S}_{4}\right)$ [73]. Oxidation roasting of spent catalyst and subsequent $\mathrm{NaCl} / \mathrm{H}_{2} \mathrm{O}$ roasting of oxide were proposed by Biswas et al. [74], and $81.9 \%$ of V was extracted. The reactions were as follows in Equations (48) and (49):

$$
\begin{gathered}
4 \mathrm{~V}_{3} \mathrm{~S}_{4}+31 \mathrm{O}_{2}=6 \mathrm{~V}_{2} \mathrm{O}_{5}+16 \mathrm{SO}_{2} \\
\mathrm{~V}_{2} \mathrm{O}_{5}+2 \mathrm{NaCl}+2 \mathrm{H}_{2} \mathrm{O}=2 \mathrm{NaVO}_{3}+2 \mathrm{HCl}
\end{gathered}
$$

There are two processes (direct chlorination and roasting chlorination) for recovering vanadium from spent hydrodesulphurization catalysts by $\mathrm{Cl}_{2}$ chlorination.

In addition to metal elements such as vanadium and molybdenum, spent catalysts also contain elemental carbon and sulfur. Direct chlorination of spent catalysts was investigated by Gaballah et al. [75]. In order to recover $\mathrm{Mo}, \mathrm{V}, \mathrm{Ni}$ and $\mathrm{Co}, \mathrm{Cl}_{2} / \mathrm{N}_{2}, \mathrm{Cl}_{2}$ /air, and $\mathrm{Cl}_{2} / \mathrm{CO} / \mathrm{N}_{2}$, gas mixtures were used to chloride spent catalysts. Vanadium sulphide was chlorinated to vanadium chloride as expressed in the reaction Equations (50)-(52). A total 
of $75 \%$ of $\mathrm{V}$ in the form of $\mathrm{VCl}_{4}$ and / or $\mathrm{VOCl}_{3}$ was recovered by $\mathrm{Cl}_{2}$ /air gas mixture at less than $600{ }^{\circ} \mathrm{C}$.

$$
\begin{gathered}
1 / 7 \mathrm{~V}_{2} \mathrm{~S}_{3}+\mathrm{Cl}_{2}=2 / 7 \mathrm{VCl}_{4}(\mathrm{l}, \mathrm{g})+3 / 7 \mathrm{SCl}_{2} \\
1 / 4 \mathrm{~V}_{2} \mathrm{~S}_{3}+3 / 4 \mathrm{O}_{2}+\mathrm{Cl}_{2}=1 / 2 \mathrm{VCl}_{4}(\mathrm{l}, \mathrm{g})+3 / 4 \mathrm{SO}_{2} \\
1 / 3 \mathrm{~V}_{2} \mathrm{~S}_{3}+3 / 4 \mathrm{O}_{2}+\mathrm{Cl}_{2}=2 / 3 \mathrm{VOCl}_{3}(\mathrm{l}, \mathrm{g})+\mathrm{SO}_{2}
\end{gathered}
$$

Vanadium sulfide in the spent catalyst is first oxidized to oxide at $300-500{ }^{\circ} \mathrm{C}$. Vanadium oxide was chlorinated by $\mathrm{Cl}_{2} / \mathrm{N}_{2}, \mathrm{Cl}_{2} / \mathrm{O}_{2}$, or $\mathrm{Cl}_{2} / \mathrm{CO}$ in the temperature range $300^{\circ} \mathrm{C}$ to $600{ }^{\circ} \mathrm{C}$. Finally, $\mathrm{V}$ was volatilized in the form of $\mathrm{VCl}_{4}$ or $\mathrm{VOCl}_{3}$ to achieve separation from other elements $(\mathrm{Co}, \mathrm{Ni})$. A total of $65 \%$ of $\mathrm{V}$ from oxidized $\mathrm{V}$ sulfide can be recovered by $\mathrm{Cl}_{2} / \mathrm{N}_{2}=1$ at $500{ }^{\circ} \mathrm{C}$ for $19 \mathrm{~h}$. Meanwhile, $\mathrm{V}$ sulfide is directly chlorinated without roasting, and $80 \%$ of $\mathrm{V}$ can be recovered by $\mathrm{Cl}_{2} / \mathrm{N}_{2}=1$ at $500{ }^{\circ} \mathrm{C}$ for $0.5 \mathrm{~h} \mathrm{[76] \text {. }}$

The affinity of metal to oxide is stronger than that of metal to sulfur. Under the same conditions, sulfides are easier to chlorinate than oxides. Thus, direct chlorination of vanadium sulfide is better than chlorination after oxidation of vanadium sulfide [77].

\subsection{Chlorination of $\mathrm{V}_{2} \mathrm{O}_{5}$}

Mink et al. [78] reported that $\mathrm{CCl}_{4}$ reversibly dissociate and adsorbs on the two exposed vanadium atoms of the basic (001) plane of $\mathrm{V}_{2} \mathrm{O}_{5}$ before the chlorination reaction. The mechanism of chlorination of $\mathrm{V}_{2} \mathrm{O}_{5}$ by $\mathrm{CCl}_{4}$ was analyzed by MS and XPS. Before the formation of the volatile final product $\mathrm{VOCl}_{3}$, the surface vanadium atoms gradually acquire two chlorine atoms [79]. The kinetics of chlorination of $\mathrm{V}_{2} \mathrm{O}_{5}$ by $\mathrm{CCl}_{4}$ was investigated by Jean et al. [80]. A total of $87 \%$ of $\mathrm{V}_{2} \mathrm{O}_{5}$ could be chlorinated by $\mathrm{CCl}_{4}$ at $480{ }^{\circ} \mathrm{C}$ in $30 \mathrm{~min}$. Chlorination reaction conforms to topochemical reaction model. According to analysis of kinetics results, the following mechanisms, Equations (53)-(58), at different temperatures, were proposed.

a. $\quad 280-370{ }^{\circ} \mathrm{C}$

$$
\begin{gathered}
\mathrm{V}_{2} \mathrm{O}_{5}+\mathrm{CCl}_{4} \stackrel{\text { slow }}{\rightarrow} \mathrm{VOCl}_{3}+\mathrm{VO}_{2} \mathrm{Cl}+\mathrm{CO}_{2} \\
\mathrm{VO}_{2} \mathrm{Cl}+\mathrm{CCl}_{4} \stackrel{\text { fast }}{\rightarrow} \mathrm{VCl}_{5}+\mathrm{CO}_{2} \\
\mathrm{VCl}_{5} \stackrel{\text { fast }}{\rightarrow} \mathrm{VCl}_{4}+1 / 2 \mathrm{Cl}_{2} \\
\mathrm{VOCl}_{3}+\mathrm{CCl}_{4}+1 / 2 \mathrm{Cl}_{2} \stackrel{\text { fast }}{\rightarrow} \mathrm{VCl}_{4}+\mathrm{COCl}_{2}+\mathrm{Cl}_{2}
\end{gathered}
$$

b. $\quad 410-515^{\circ} \mathrm{C}$

$$
\begin{gathered}
\mathrm{CCl}_{4} \stackrel{\text { fast }}{\rightarrow} \mathrm{C}+4 \mathrm{Cl} \\
\mathrm{V}_{2} \mathrm{O}_{5}+\mathrm{C}+4 \mathrm{Cl} \stackrel{\text { slow }}{\rightarrow} \mathrm{VOCl}_{3}+\mathrm{VO}_{2} \mathrm{Cl}+\mathrm{CO}_{2}
\end{gathered}
$$

The whole reaction can be expressed by the following Formula (59)

$$
\mathrm{V}_{2} \mathrm{O}_{5}+3 \mathrm{CCl}_{4}=2 \mathrm{VCl}_{4}+2 \mathrm{CO}_{2}+\mathrm{COCl}_{2}+\mathrm{Cl}_{2}
$$

Gaballah et al. [81] studied kinetics of chlorination of $\mathrm{V}_{2} \mathrm{O}_{5}$ with $\mathrm{Cl}_{2}-\mathrm{CO}-\mathrm{N}_{2}, \mathrm{Cl}_{2}-\mathrm{N}_{2}$, and $\mathrm{Cl}_{2}$-air gas mixtures. Thermodynamic calculation showed that chlorinated product was mainly $\mathrm{VOCl}_{3}$ during the $\mathrm{Cl}_{2}$ chlorination of $\mathrm{V}_{2} \mathrm{O}_{5}$. However, $\mathrm{VCl}_{4}$ may be formed during the carbochlorination of vanadium pentoxide. The results of kinetics indicated that the rate-control step of $\mathrm{V}_{2} \mathrm{O}_{5}$ chlorination process between $500{ }^{\circ} \mathrm{C}$ and $570{ }^{\circ} \mathrm{C}$ with $\mathrm{Cl}_{2}-\mathrm{N}_{2}$ was a chemical reaction. Pore diffusion and chemical reaction were the limiting 
step for the $\mathrm{V}_{2} \mathrm{O}_{5}$ chlorination in the temperature range of $570{ }^{\circ} \mathrm{C}$ to $650{ }^{\circ} \mathrm{C}$. In $\mathrm{Cl}_{2}$-CO$\mathrm{N}_{2}$ atmosphere, the limiting step of carbochlorination of $\mathrm{V}_{2} \mathrm{O}_{5}$ at $400-620^{\circ} \mathrm{C}$ was the chemical reaction. Brocchi et al. [6] systematically studied the carbon-chlorination of $\mathrm{V}_{2} \mathrm{O}_{5}$ from thermodynamics between $627^{\circ} \mathrm{C}$ and $1327{ }^{\circ} \mathrm{C}$. In carbon-chlorination reaction of $\mathrm{V}_{2} \mathrm{O}_{5}$, the most stable vanadium oxychloride and vanadium chloride are $\mathrm{VOCl}_{3}$ and $\mathrm{VCl}_{4}$, respectively. E. Mccarley et al. [82] reported a process for preparing high-purity $\mathrm{V}_{2} \mathrm{O}_{5}$ (maximum of $100 \mathrm{ppm}$ impurities) by carbon chlorination using $\mathrm{V}$ red cake ( $88 \mathrm{wt} \%$ of $\mathrm{V}_{2} \mathrm{O}_{5}$ ) as raw materials. Pap et al. [83] reported that the chlorination of $\mathrm{V}_{2} \mathrm{O}_{5}$ by three chlorinating agents $\left(\mathrm{Cl}_{2}, \mathrm{COCl}_{2}\right.$ and $\left.\mathrm{CCl}_{4}\right)$ is compared from the aspects of thermodynamics and kinetics. The results showed that $\mathrm{V}_{2} \mathrm{O}_{5}$ can be chlorinated thermodynamically by $\mathrm{COCl}_{2}$ and $\mathrm{CCl}_{4}$ at $127^{\circ} \mathrm{C}$, and the chlorinated products were $\mathrm{VOCl}_{3}$ and $\mathrm{CO}_{2}$. However, the reaction of $\mathrm{V}_{2} \mathrm{O}_{5}$ with $\mathrm{Cl}_{2}$ can occur obviously when the temperature exceeds $477^{\circ} \mathrm{C}$. The chlorinated product was $\mathrm{VOCl}_{3}$ and $\mathrm{O}_{2}$. The chlorination kinetics showed that the apparent activation energy of $\mathrm{V}_{2} \mathrm{O}_{5}$ chlorinated by $\mathrm{Cl}_{2}, \mathrm{CCl}_{4}$, and $\mathrm{COCl}_{2}$ were $126 \mathrm{~kJ} / \mathrm{mol}$, $77 \mathrm{~kJ} / \mathrm{mol}$, and $48 \mathrm{~kJ} / \mathrm{mol}$, respectively. High-purity $\mathrm{V}_{2} \mathrm{O}_{5}(99.95 \mathrm{wt} \%)$ is prepared by chlorinating industrial grade $\mathrm{V}_{2} \mathrm{O}_{5}(96.7 \mathrm{wt} \%)$ with $\mathrm{AlCl}_{3}$. The reactions involved are as follows in Equations (60)-(64). Under the protection of purity $\mathrm{Ar}$, the chlorination ratio of $\mathrm{V}_{2} \mathrm{O}_{5}$ at a $\mathrm{V}_{2} \mathrm{O}_{5}: \mathrm{AlCl}_{3}$ mole ratio of $1: 6,180^{\circ} \mathrm{C}$, and $3.5 \mathrm{~h}$ was $62 \%$, and a large amount of $\mathrm{VOCl}_{3}$ was collected. When $\mathrm{NaCl}$ is added to the chlorination reaction system, the chlorination ratio of vanadium can reach $83.4 \%$ at mole ratio of $\mathrm{AlCl}_{3}: \mathrm{V}_{2} \mathrm{O}_{5}$ of $6: 1$ and mole fraction of $\mathrm{NaCl}$ of 0.6 in the $\mathrm{NaCl}-\mathrm{AlCl}_{3}$ system [84,85].

$$
\begin{gathered}
2 \mathrm{AlCl}_{3}+\mathrm{V}_{2} \mathrm{O}_{5}=\mathrm{Al}_{2} \mathrm{O}_{3}+2 \mathrm{VOCl}_{3}(\mathrm{~g}) \\
6 \mathrm{VOCl}_{3}+20 \mathrm{NH}_{3} \cdot \mathrm{H}_{2} \mathrm{O}=\left(\mathrm{NH}_{4}\right)_{2} \mathrm{~V}_{6} \mathrm{O}_{16}+18 \mathrm{NH}_{4} \mathrm{Cl}+10 \mathrm{H}_{2} \mathrm{O} \\
\mathrm{VOCl}_{3}+4 \mathrm{NH}_{4} \mathrm{OH}=\mathrm{NH}_{4} \mathrm{VO}_{3}+3 \mathrm{NH}_{4} \mathrm{Cl}+2 \mathrm{H}_{2} \mathrm{O} \\
\left(\mathrm{NH}_{4}\right)_{2} \mathrm{~V}_{6} \mathrm{O}_{16}=3 \mathrm{~V}_{2} \mathrm{O}_{5}+2 \mathrm{NH}_{3}+\mathrm{H}_{2} \mathrm{O} \\
\mathrm{NH}_{4} \mathrm{VO}_{3}=\mathrm{V}_{2} \mathrm{O}_{5}+2 \mathrm{NH}_{3}+\mathrm{H}_{2} \mathrm{O}
\end{gathered}
$$

\subsection{Chlorination Extraction of Vanadium from Other Vanadium-Containing Materials}

Petroleum coke, fly ash and carbonaceous gold ore also contain a certain amount of vanadium. 0.6 Mt/year of petroleum coke was produced from Syrian petroleum refineries. The extraction ratio of vanadium can reach $60 \%$ by NaCl-roasting [86]. The vanadium content in fly ash is as low as $1-7 \%$. The fly ash was treated by acid leaching, oxidation of $\mathrm{NaClO}_{3}$, and precipitation [87]. Murase et al. [88] investigated extraction and separation of vanadium from a fly ash of Orimulsion. Air- $\mathrm{Cl}_{2}$ or $\mathrm{N}_{2}-\mathrm{Cl}_{2}$ gas mixture were used to chlorinate valuable elements $(\mathrm{V}, \mathrm{Ni}$ and $\mathrm{Mg}$ ). The separation of $\mathrm{V}$ and Fe were achieved by controlled temperature of chlorination. $\mathrm{V}$ and Fe was selectively extracted by chlorination at $400{ }^{\circ} \mathrm{C}$ and $500{ }^{\circ} \mathrm{C}$, respectively. $\mathrm{Mg}$ and $\mathrm{Ni}$ in residue were extracted by chlorination of $\mathrm{N}_{2}-\mathrm{Cl}_{2}-\mathrm{Al}_{2} \mathrm{Cl}_{6}(\mathrm{~g})$ at $600{ }^{\circ} \mathrm{C}$. The extraction and separation of $\mathrm{V}, \mathrm{Ni}$ and $\mathrm{Mg}$ were successfully achieved by the method of chlorination. The content of vanadium in refractory carbonaceous gold ore is $1.1 \mathrm{wt} \%$. Wang et al. [89] investigated extraction and separation of vanadium from carbonaceous gold ore by $\mathrm{NaCl}$ roasting. After $\mathrm{NaCl}$ roasting, $\mathrm{Au}$ volatilizes in the form of $\mathrm{AuCl}_{3}$ and $\mathrm{V}$ in the form of $\mathrm{NaVO}_{3}$ remains in the roasted solid. The reactions were as follows in Equations (65)-(69).

$$
\begin{gathered}
4 \mathrm{FeS}_{2}+11 \mathrm{O}_{2}=\mathrm{Fe}_{2} \mathrm{O}_{3}+8 \mathrm{SO}_{2} \\
\mathrm{SO}_{2}+2 \mathrm{NaCl}+\mathrm{O}_{2}=\mathrm{Na}_{2} \mathrm{SO}_{4}+\mathrm{Cl}_{2} \\
4 \mathrm{~V}_{\mathrm{x}} \mathrm{O}_{\mathrm{y}}+(5 \mathrm{x}-2 \mathrm{y}) \mathrm{O}_{2}=2 \mathrm{xV}_{2} \mathrm{O}_{5}(1 \leq \mathrm{x} \leq 2 ; 2 \leq \mathrm{y} \leq 4) \\
2 \mathrm{~V}_{2} \mathrm{O}_{5}+4 \mathrm{NaCl}+\mathrm{O}_{2}=4 \mathrm{NaVO}_{3}+2 \mathrm{Cl}_{2} \\
2 \mathrm{Au}+3 \mathrm{Cl}_{2}=2 \mathrm{AuCl}_{3}
\end{gathered}
$$


The influences of experiment conditions including $\mathrm{NaCl}$ dosage, time and temperature were studied. Under optimal process conditions, (air gas flow rate $1 \mathrm{~L} / \mathrm{min}, 4 \mathrm{~h}, 800{ }^{\circ} \mathrm{C}$, $\mathrm{NaCl} 10 \%$ ), the extraction ratios of $\mathrm{V}$ and $\mathrm{Au}$ are $85.3 \%$ and $92 \%$.

\subsection{Treatments of Chlor-Containing Compounds in Gas, Solid and Solution}

Regarding the $\mathrm{Cl}_{2}$ and $\mathrm{HCl}$ off-gas generated in the chlorination process, the first method is recycling, and the second method is the absorption of alkaline solution. The chloride in the solid can be washed to remove chloride ions. The chlor-containing wastewater can be treated by solvent extraction, the electrochemical method, separation interception method, the principle of precipitation, and ion exchange [90].

\section{Conclusions and Outlook}

The research progress on the treatment of vanadium-containing materials with various chlorinating agents (solid and gas) is summarized in terms of thermodynamics and kinetics.

The $\mathrm{NaCl}$ roasting method is used to treat vanadium titanomagnetite, vanadium slag, stone, spent catalysts, petroleum coke, and carbonaceous gold ore. The $\mathrm{NaCl}$ roasting method has the characteristics of short process, less investment and less equipment, etc. In the 1970s, in China, the price of vanadium was very high and hundreds of small-scale vanadium extraction plants adopted the $\mathrm{NaCl}$ roasting method to extract vanadium from vanadium-containing materials (stone coal) [63]. However, $\mathrm{Cl}_{2}$ and $\mathrm{HCl}$ generated during the $\mathrm{NaCl}$ roasting process makes it highly demanding for the equipment's anti-corrosion performance. The environmental pollution caused by $\mathrm{Cl}_{2}$ and $\mathrm{HCl}$ gas and the threat of $\mathrm{Cl}_{2}$ and $\mathrm{HCl}$ gas to workers' health are also fatal defects of $\mathrm{NaCl}$ roasting. Due to increasingly strict environmental protection policies, the $\mathrm{NaCl}$ roasting method has become outdated and has gradually been replaced by other roasting methods.

The demand for high-purity vanadium pentoxide is increasing in all-vanadium flow batteries and high-purity metal vanadium. Therefore, efficient preparation of high-purity vanadium pentoxide is urgently needed [91]. Due to the low melting point and boiling point of vanadium chloride, vanadium chloride has a greater advantage than vanadium oxide in separation and enrichment. The advantages of chlorination method in the preparation of high-purity vanadium are very obvious, and it has very good development prospects.

Trivalent vanadium oxide is difficult to leach. Thus, the traditional vanadium extraction method is to oxidize vanadium to pentavalent vanadium for extraction. However, the toxicity of vanadium compounds increases with the increase of vanadium valence, and the pentavalent vanadium compounds are the most toxic. More than $90 \%$ of vanadium produced in industry is added to steel in the form of vanadium alloys. Trivalent vanadium oxide can be chlorinated to $\mathrm{VCl}_{3}$ by $\mathrm{AlCl}_{3}$. Metal $\mathrm{V}$ can be obtained by reduction or electrolysis of $\mathrm{VCl}_{3}$. Thus, the direct chlorination of low-valent vanadium is also a very promising process.

Author Contributions: Conceptualization, S.L. and L.W.; methodology, L.W.; validation, S.L., W.X., and L.W.; formal analysis, S.L.; investigation, S.L.; resources, W.X.; data curation, W.X.; writingoriginal draft preparation, S.L. and L.W.; writing—review and editing, L.W.; visualization, S.L. and W.X.; supervision, L.W.; funding acquisition, S.L. and L.W. All authors have read and agreed to the published version of the manuscript.

Funding: The authors are grateful for the financial support of this work from the National Natural Science Foundation of China (No. 51904286, 51922003, 51734002).

Data Availability Statement: The data presented in this study are available from the corresponding author, upon reasonable request.

Conflicts of Interest: The authors declare no conflict of interest. 


\section{References}

1. Peng, H. A literature review on leaching and recovery of vanadium. J. Environ. Chem. Eng. 2019, 7, 103313. [CrossRef]

2. Bauer, G.; Güther, V.; Hess, H.; Otto, A.; Roidl, O.; Roller, H.; Sattelberger, S. Vanadium and Vanadium Compounds; Excerpt from Ullmann's; Wiley-VCH Verlag GmbH: Weinheim, Germany, 2002.

3. Del Carpio, E.; Hernández, L.; Ciangherotti, C.; Coa, V.V.; Jiménez, L.; Lubes, V.; Lubes, G. Vanadium: History, chemistry, interactions with $\alpha$-amino acids and potential therapeutic applications. Coord. Chem. Rev. 2018, 372, 117-140. [CrossRef] [PubMed]

4. Zhao, Q.S.; Li, Z.J. Vanadium Metallurgy(fine)/Nonferrous Metals Theory and Technology Frontier Series; Central South University Press: Changsha, China, 2015.

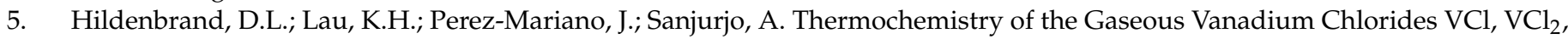
$\mathrm{VCl}_{3}$, and $\mathrm{VCl}_{4}$. J. Phys. Chem. A 2008, 112, 9978-9982. [CrossRef] [PubMed]

6. Aregay, G.G.; Ali, J.; Shahzad, A.; Lfthikar, J.; Oyekunle, D.T.; Chen, Z.Q. Application of layered double hydroxide enriched with electron rich sulfide moieties $\left(\mathrm{S}_{2} \mathrm{O}_{4}{ }^{2-}\right)$ for efficient and selective removal of vanadium $(\mathrm{V})$ from diverse aqueous medium. Sci. Total Environ. 2021, 792, 148543. [CrossRef]

7. Zhang, R.C.; Leiviskä, T. Surface modification of pine bark with quaternary ammonium groups and its use for vanadium removal. Chem. Eng. J. 2020, 385, 123987. [CrossRef]

8. Petranikova, M.; Tkaczyk, A.; Bartl, A.; Amato, A.; Lapkovskis, V.; Tunsu, C. Vanadium sustainability in the context of innovative recycling and sourcing development. Waste Manag. 2020, 113, 521-544. [CrossRef]

9. Gilligan, R.; Nikoloski, A.N. The extraction of vanadium from titanomagnetites and other sources. Miner. Eng. 2020, $146,106106$. [CrossRef]

10. Kologrieva, U.; Volkov, A.; Zinoveev, D.; Krasnyanskaya, I.; Stulov, P.; Wainstein, D. Investigation of vanadium-containing sludge oxidation roasting process for vanadium extraction. Metals 2021, 11, 100. [CrossRef]

11. Brocchi, E.; Navarro, R.; Moura, F. A chemical thermodynamics review applied to $\mathrm{V}_{2} \mathrm{O}_{5}$ chlorination. Thermochim. Acta 2013, 559, 1-16. [CrossRef]

12. Zhou, X.J.; Cui, X.M.; Peng, F.C. Thermodynamics of Ti, V and Their Chemical Compounds; Metallurgical Industry Press: Beijing, China, 2019. (In Chinese)

13. Wang, H.-J.; Feng, Y.-L.; Li, H.-R.; Kang, J.-X. Simultaneous extraction of gold and zinc from refractory carbonaceous gold ore by chlorination roasting process. Trans. Nonferr. Met. Soc. China 2020, 30, 1111-1123. [CrossRef]

14. Fan, C.; $\mathrm{Xu}$, J.; Yang, H.; Zhu, Q. High-purity, low- $\mathrm{Cl} \mathrm{V}_{2} \mathrm{O}_{5}$ via the gaseous hydrolysis of $\mathrm{VOCl}_{3}$ in a fluidized bed. Particuology 2020, 49, 9-15. [CrossRef]

15. Kim, J.Y.; Lee, M.S.; Jung, E.J. A study of formation behavior of porous structure induced by selective chlorination of ilmenite. Mater. Chem. Phys. 2020, 241, 122433. [CrossRef]

16. Xing, Z.; Cheng, G.; Yang, H.; Xue, X.; Jiang, P. Mechanism and application of the ore with chlorination treatment: A review. Miner. Eng. 2020, 154, 106404. [CrossRef]

17. Jena, S.K.; Dash, N.; Angadi, S.I. A novel application of Linz-Donawitz Slag for potash recovery from waste mica scrap using chlorination roasting coupled water leaching process. Sep. Sci. Technol. 2021, 56, 2310-2326. [CrossRef]

18. Mochizuki, Y.; Tsubouchi, N.; Sugawara, K. Separation of valuable elements from steel making slag by chlorination. Resour. Conserv. Recycl. 2020, 158, 104815. [CrossRef]

19. Long, H.L.; Li, H.Y.; Pei, J.N.; Srinivasakannan, C.; Yin, S.H.; Zhang, L.B.; Ma, A.Y.; Li, S.W. Cleaner recovery of multiple valuable metals from cyanide tailings via chlorination roasting. Sep. Sci. Technol. 2021, 56, 2113-2123. [CrossRef]

20. Guo, X.; Zhang, B.; Wang, Q.; Li, Z.; Tian, Q. Recovery of Zinc and Lead from Copper Smelting Slags by Chlorination Roasting. JOM 2021, 73, 1861-1870. [CrossRef]

21. Kim, J.; Lee, Y.R.; Jung, E.J. A Study on the Roasting Process for Efficient Selective Chlorination of Ilmenite Ores. JOM 2021, 73 , 1495-1502. [CrossRef]

22. Kang, J.; Okabe, T.H. Thermodynamic Consideration of the Removal of Iron from Titanium Ore by Selective Chlorination. Met. Mater. Trans. A 2014, 45, 1260-1271. [CrossRef]

23. Jena, P.K.; Brocchi, E.A. Metal extraction through chlorine metallurgy. Miner. Process. Extr. Metall. Rev. 1997, 16, $211-237$. [CrossRef]

24. Li, H.Y.; Li, S.W.; Ma, P.C.; Zhou, Z.F.; Long, H.L.; Peng, J.H.; Zhang, L.B. Evaluation of a cleaner production for cyanide tailings by chlorination thermal treatments. J. Clean. Prod. 2021, 281, 124195. [CrossRef]

25. Chen, S.; Guan, J.; Yuan, H.; Wu, H.C.; Gu, W.X.; Gao, G.L.; Guo, Y.G.; Dia, J.; Su, R.J. Behavior and Mechanism of Indium Extraction from Waste Liquid-Crystal Display Panels by Microwave-Assisted Chlorination Metallurgy. JOM 2021, 73, 1290-1300. [CrossRef]

26. Cui, F.; Mu, W.; Zhai, Y.; Guo, X. The selective chlorination of nickel and copper from low-grade nickel-copper sulfide-oxide ore: Mechanism and kinetics. Sep. Purif. Technol. 2020, 239, 116577. [CrossRef]

27. Kumari, A.; Raj, R.; Randhawa, N.; Sahu, S.K. Energy efficient process for recovery of rare earths from spent NdFeB magnet by chlorination roasting and water leaching. Hydrometallurgy 2021, 201, 105581. [CrossRef]

28. Okabe, P.; Newton, M.; Rappleye, D.; Simpson, M.F. Gas-solid reaction pathway for chlorination of rare earth and actinide metals using hydrogen and chlorine gas. J. Nucl. Mater. 2020, 534, 152156. [CrossRef] 
29. Xie, K.; Hu, H.; Xu, S.; Chen, T.; Huang, Y.; Yang, Y.; Yang, F.; Yao, H. Fate of heavy metals during molten salts thermal treatment of municipal solid waste incineration fly ashes. Waste Manag. 2020, 103, 334-341. [CrossRef]

30. Chen, D.H. Annual evaluation for vanadium industry in 2018. HeBei Metall. 2019, 284, 5-15. (In Chinese)

31. Fan, G.; Wang, M.; Dang, J.; Zhang, R.; Lv, Z.; He, W.; Lv, X. A novel recycling approach for efficient extraction of titanium from high-titanium-bearing blast furnace slag. Waste Manag. 2021, 120, 626-634. [CrossRef] [PubMed]

32. Zhang, R.; Dang, J.; Liu, D.; Lv, Z.; Fan, G.; Hu, L. Reduction of perovskite-geikielite by methane-hydrogen gas mixture: Thermodynamic analysis and experimental results. Sci. Total Environ. 2020, 699, 134355. [CrossRef] [PubMed]

33. Zheng, F.; Chen, F.; Guo, Y.; Jiang, T.; Travyanov, A.Y.; Qiu, G. Kinetics of Hydrochloric Acid Leaching of Titanium from Titanium-Bearing Electric Furnace Slag. JOM 2016, 68, 1476-1484. [CrossRef]

34. Yang, S.L. Non-Blast Furnace Smelting Technology of Vanadium-Titanium Magnetite; Metallurgical Industry Press: Beijing, China, 2012. (In Chinese)

35. Bhaskarasarma, P.; Rao, P.; Jena, P. Extraction of vanadium from titaniferrous vanadium bearing magnetities by salt roasting. Trans. Ind. Inst. Met. 1980, 33, 166-169.

36. Jena, P.K.; Brocchi, E.A. Halide Metallurgy of Refractory Metals. Miner. Process. Extr. Met. Rev. 1992, 10, 29-40. [CrossRef]

37. Zheng, H.Y.; Sun, Y.; Lu, J.W.; Dong, J.H.; Zhang, W.L.; Shen, F.M. Vanadium extraction from vanadium-bearing titano-magnetite by selective chlorination using chloride wastes (FeClx). J. Cent. South Univ. 2017, 24, 311-317. [CrossRef]

38. Lee, J.-C.; Kim, E.-Y.; Chung, K.W.; Kim, R.; Jeon, H.-S. A review on the metallurgical recycling of vanadium from slags: Towards a sustainable vanadium production. J. Mater. Res. Technol. 2021, 12, 343-364. [CrossRef]

39. Liu, S.Y. Fundamental Studies on Selective Chlorination of Valuable Elements (Fe, Mn, V, Cr and Ti) from Vanadium Slag and Utilizations towards High Value. Ph.D. Thesis, University of Science and Technology Beijing, Beijing, China, 2019.

40. Xiang, J.; Huang, Q.; Lv, X.; Bai, C. Extraction of vanadium from converter slag by two-step sulfuric acid leaching process. J. Clean. Prod. 2018, 170, 1089-1101. [CrossRef]

41. Liu, S.Y.; Wang, L.J.; Chou, K.C. Viscosity measurement of $\mathrm{FeO}-\mathrm{SiO}_{2}-\mathrm{V}_{2} \mathrm{O}_{3}-\mathrm{TiO}_{2}$ slags in the temperature range of $1644-1791 \mathrm{~K}$ and modelling by using ion-oxygen parameter. Ironmak. Steelmak. 2018, 45, 641-647. [CrossRef]

42. Ji, Y.; Shen, S.; Liu, J.; Xue, Y. Cleaner and effective process for extracting vanadium from vanadium slag by using an innovative three-phase roasting reaction. J. Clean. Prod. 2017, 149, 1068-1078. [CrossRef]

43. Zhang, G.Q.; Hu, T.; Liao, W.J.; Ma, X.D. An energy-efficient process of leaching vanadium from roasted tablet of ammonium sulfate, vanadium slag and silica. J. Environ. Chem. Eng. 2021, 9, 105332. [CrossRef]

44. Li, H.; Wang, X.H.; Zhou, R.Z. Experimental study on chloridizing volatilization of Ga during sodiumination roasting of V-slag. Iron Steel Vanadium Titan. 1993, 14, 44-50. (In Chinese)

45. Wang, H.G.; Wang, M.; Wang, X.W. Leaching behaviour of chromium during vanadium extraction from vanadium slag. Miner. Process. Extr. Met. 2015, 124, 127-131. [CrossRef]

46. Liu, S.; Shen, S.; Chou, K. An effective process for simultaneous extraction of valuable metals (V, Cr, Ti, Fe, Mn) from vanadium slag using acidic sodium chlorate solution under water bath conditions. J. Min. Met. Sect. B Met. 2018, 54, 153-159. [CrossRef]

47. Sun, Y. Comprehensive Utilization of Vanadium-Bearing Titanomagnetite with Extracting Vanadium by Selective Chlorination technology. Ph.D. Thesis, Northeastern University, Shenyang, China, 2015. (In Chinese).

48. Du, G.; Fan, C.; Yang, H.; Zhu, Q. Selective extraction of vanadium from pre-oxidized vanadium slag by carbochlorination in fluidized bed reactor. J. Clean. Prod. 2019, 237, 117765. [CrossRef]

49. Liu, S.-Y.; Li, S.-J.; Wu, S.; Wang, L.-J.; Chou, K.-C. A novel method for vanadium slag comprehensive utilization to synthesize Zn-Mn ferrite and Fe-V-Cr alloy. J. Hazard. Mater. 2018, 354, 99-106. [CrossRef] [PubMed]

50. Liu, S.; Wang, L.; Chou, K. Selective Chlorinated Extraction of Iron and Manganese from Vanadium Slag and Their Application to Hydrothermal Synthesis of $\mathrm{MnFe}_{2} \mathrm{O}_{4}$. ACS Sustain. Chem. Eng. 2017, 5, 10588-10596. [CrossRef]

51. Liu, S.; Wang, L.; Chou, K.-C.; Kumar, R.V. Electrolytic preparation and characterization of VCr alloys in molten salt from vanadium slag. J. Alloy. Compd. 2019, 803, 875-881. [CrossRef]

52. Liu, S.; Wang, L.; Chou, K. A Novel Process for Simultaneous Extraction of Iron, Vanadium, Manganese, Chromium, and Titanium from Vanadium Slag by Molten Salt Electrolysis. Ind. Eng. Chem. Res. 2016, 55, 12962-12969. [CrossRef]

53. Liu, S.; He, X.; Wang, Y.; Wang, L. Cleaner and effective extraction and separation of iron from vanadium slag by carbothermic reduction-chlorination-molten salt electrolysis. J. Clean. Prod. 2021, 284, 124674. [CrossRef]

54. Liu, S.Y.; Wang, L.J.; Chou, K.C. Innovative method for minimization of waste containing Fe, Mn and Ti during comprehensive utilization of vanadium slag. Waste Manag. 2021, 127, 179-188. [CrossRef]

55. Liu, S.-Y.; Zhen, Y.-L.; He, X.-B.; Wang, L.-J.; Chou, K.-C. Recovery and separation of Fe and Mn from simulated chlorinated vanadium slag by molten salt electrolysis. Int. J. Miner. Met. Mater. 2020, 27, 1678-1686. [CrossRef]

56. Menad, N.-E.; Kanari, N.; Save, M. Recovery of high grade iron compounds from LD slag by enhanced magnetic separation techniques. Int. J. Miner. Process. 2014, 126, 1-9. [CrossRef]

57. Seron, A.; Menad, N.; Galle-Cavalloni, P.; Bru, K. Selective Recovery of Vanadium by Oxy-carbochlorination of Basic Oxygen Furnace Slag: Experimental Study. J. Sustain. Met. 2020, 6, 478-490. [CrossRef]

58. Bin, Z.Y. Progress of the research on extraction of vanadium pentoxide from black shale and the market of the $\mathrm{V}_{2} \mathrm{O}_{5} . \mathrm{Hu}-\mathrm{Nan}$ Nonferr. Met. 2006, 22, 16-20. (In Chinese) 
59. Xiao, W.D. Mineralogy of black shale from Shanglin of Guangxi and vanadium extraction with hydrometallurgical process. Nonferr. Met. 2007, 59, 85-90.

60. He, D.; Feng, Q.; Zhang, G.; Ou, L.; Lu, Y. An environmentally-friendly technology of vanadium extraction from stone coal. Miner. Eng. 2007, 20, 1184-1186. [CrossRef]

61. Hu, K.L.; Liu, X.H. Review of roasting processing of vanadium-bearing carbonaceous shale. Rare Met. Cem. Carbides 2015, 43, 1-7.

62. Lin, H.L.; Fan, B.W. Study on mechanism of phase transformation during roasting and extracting vanadium from Fangshankou bone coal. Chin. J. Rare Met. 2001, 25, 273-277. (In Chinese)

63. Zhang, Y.M.; Bao, S.X.; Liu, T.; Chen, T.J.; Huang, J. The technology of extracting vanadium from stone coal in China: History, current statues and future prospects. Hydrometallurgy 2011, 109, 116-124. [CrossRef]

64. Wang, M.; Huang, S.; Chen, B.; Wang, X. A review of processing technologies for vanadium extraction from stone coal. Miner. Process. Extr. Met. 2020, 129, 290-298. [CrossRef]

65. Bie, S.; Wang, Z.J.; Li, Q.H.; Zhang, Y.G. Review of vanadium extraction from stone coal by roasting technique with sodium chloride and calcium oxide. Chin. J. Rare Met. 2010, 34, 291-297. (In Chinese)

66. Wang, H.S. Extraction of vanadtum from stone coal by roasting in the presence of sodium salts. Min. Metall. Eng. 1994, 14, 49-52.

67. Wan, J.Y.; Chen, T.J.; Han, J.; Feng, Y. Thermodynamics analysis of chlorination volatilization enrichment process of black shale. Nonferr. Met. (Extr. Metall.) 2018, 5, 50-55. (In Chinese)

68. Zhang, Y.; Hu, Y.; Bao, S. Vanadium emission during roasting of vanadium-bearing stone coal in chlorine. Miner. Eng. 2012, 30, 95-98. [CrossRef]

69. Li, C.-X.; Wei, C.; Deng, Z.-G.; Li, M.-T.; Li, X.-B.; Fan, G. Recovery of vanadium from black shale. Trans. Nonferr. Met. Soc. China 2010, 20, s127-s131. [CrossRef]

70. Erust, C.; Akcil, A.; Bedelova, Z.; Anarbekov, K.; Baikonurova, A.; Tuncuk, A. Recovery of vanadium from spent catalysts of sulfuric acid plant by using inorganic and organic acids: Laboratory and semi-pilot tests. Waste Manag. 2016, 49, 455-461. [CrossRef]

71. Li, Z.; Chen, M.; Zhang, Q.; Liu, X.; Saito, F. Mechanochemical processing of molybdenum and vanadium sulfides for metal recovery from spent catalysts wastes. Waste Manag. 2017, 60, 734-738. [CrossRef] [PubMed]

72. Beolchini, F.; Fonti, V.; Dell'Anno, A.; Rocchetti, L.; Vegliò, F. Assessment of biotechnological strategies for the valorization of metal bearing wastes. Waste Manag. 2012, 32, 949-956. [CrossRef]

73. Akcil, A.; Vegliò, F.; Ferella, F.; Okudan, M.D.; Tuncuk, A. A review of metal recovery from spent petroleum catalysts and ash. Waste Manag. 2015, 45, 420-433. [CrossRef]

74. Biswas, R.; Wakihara, M.; Taniguchi, M. Recovery of vanadium and molybdenum from heavy oil desulphurization waste catalyst. Hydrometallurgy 1985, 14, 219-230. [CrossRef]

75. Gaballah, I.; Djona, M. Recovery of Co, Ni, Mo and V from unroasted spent hydrorefining catalysts by selective chlorination. Metall. Mater. Trans. B 1995, 26, 41-50. [CrossRef]

76. Gaballah, I.; Djona, M.; Mugica, J.; Solozobal, R. Valuable metals recovery from spent catalysts by selective chlorination. Resour. Conserv. Recycl. 1994, 10, 87-96. [CrossRef]

77. Zhang, J.Y. Metallurgical Physical Chemistry; Metallurgical Industry Press: Beijing, China, 2004. (In Chinese)

78. Mink, G.; Bertóti, I.; Székely, T. Chlorination of $\mathrm{V}_{2} \mathrm{O}_{5}$ by $\mathrm{CCl}_{4}$. Adsorption and steady state reaction. React. Kinet. Catal. Lett. 1985, 27, 33-38. [CrossRef]

79. Mink, G.; Bertóti, I.; Székely, T. Chlorination of $\mathrm{V}_{2} \mathrm{O}_{5}$ by $\mathrm{CCl}_{4}$, the proposed reaction mechanism. React. Kinet. Catal. Lett. 1985, 27, 39-45. [CrossRef]

80. Jena, P.; Brocchi, E.; González, J. Kinetics of Low-Temperature Chlorination of Vanadium Pentoxide by Carbon Tetrachloride Vapor. Metall. Mater. Trans. B 2005, 36, 195-199. [CrossRef]

81. Gaballah, I.; Djona, M.; Allain, E. Kinetics of chlorination and carbochlorination of vanadium pentoxide. Met. Mater. Trans. A 1995, 26, 711-718. [CrossRef]

82. McCarley, R.E.; Roddy, J.W. The preparation of high purity vanadium pentoxide by a chlorination procedure. J. Less Common Met. 1960, 2, 29-35. [CrossRef]

83. Pap, I.S.; Mink, G.; Bertóti, I.; Székely, T.; Babievskaya, I.Z.; Karmazsin, E. Comparative kinetic and thermodynamic study on the chlorination of $\mathrm{V}_{2} \mathrm{O}_{5}$ with $\mathrm{CCl}_{4}, \mathrm{COCl}_{2}$ and $\mathrm{Cl}_{2}$. J. Therm. Anal. Calorim. 1989, 35, 163-173. [CrossRef]

84. Jiang, D.-D.; Zhang, H.-L.; Xu, H.-B.; Zhang, Y. A novel method to prepare high-purity vanadium pentoxide by chlorination with anhydrous aluminum chloride. Chem. Lett. 2017, 46, 669-671. [CrossRef]

85. Jiang, D.D.; Zhang, H.L.; Xu, H.B.; Zhang, Y. Chlorination and purification of vanadium pentoxide with anhydrous aluminum chloride. J. Alloy. Compd. 2017, 709, 505-510. [CrossRef]

86. Shlewit, H.; Alibrahim, M. Extraction of sulfur and vanadium from petroleum coke by means of salt-roasting treatment. Fuel 2006, 85, 878-880. [CrossRef]

87. Vitolo, S.; Seggiani, M.; Filippi, S.; Brocchini, C. Recovery of vanadium from heavy oil and Orimulsion fly ashes. Hydrometallurgy 2000, 57, 141-149. [CrossRef]

88. Murase, K.; Nishikawa, K.I.; Ozaki, T.; Machida, K.I.; Adachi, G.Y.; Suda, T. Recovery of vanadium, nickel and magnesium from a fly ash of bitumen-in-water emulsion by chlorination and chemical transport. J. Alloy. Compd. 1998, 264, 151-156. [CrossRef] 
89. Wang, H.; Feng, Y.; Li, H.; Kang, J. The separation of gold and vanadium in carbonaceous gold ore by one-step roasting method. Powder Technol. 2019, 355, 191-200. [CrossRef]

90. Zhang, L.J.; Lv, P.; He, Y.; Li, S.W.; Chen, K.H.; Yin, S.H. Purification of chlorine-containing wastewater using solvent extraction. J. Clean. Prod. 2020, 273, 122863. [CrossRef]

91. Fan, C.; Yang, $\mathrm{H}$; Zhu, Q. Selective hydrolysis of trace $\mathrm{TiCl}_{4}$ from $\mathrm{VOCl}_{3}$ for preparation of high purity $\mathrm{V}_{2} \mathrm{O}_{5}$. Sep. Purif. Technol. 2017, 185, 196-201. [CrossRef] 